\title{
Cytotoxic and Antiviral Compounds from Bryophytes and Inedible Fungi
}

\author{
Yoshinori Asakawa', Agnieszka Ludwiczuk ${ }^{1,2}$, Toshihiro Hashimoto' \\ 1 Faculty of Pharmaceutical Sciences, Tokushima Bunri University, Yamashiro-cho, Tokushima, Japan \\ 2 Department of Pharmacognosy with Medicinal Plants Laboratory, Medical University of Lublin, Poland
}

Asakawa Y, Ludwiczuk A, Hashimoto T. Cytotoxic and Antiviral Compounds from Bryophytes and Inedible Fungi. J Pre-Clin Clin Res. 2013; 7(2): 73-85.

\section{Abstract}

Over several hundred new compounds have been isolated from the bryophytes and more than 40 new carbon skeletal terpenoids and aromatic compounds found in this class. Most of liverworts elaborate characteristic odiferous, pungent and bitter tasting compounds many of which show, antimicrobial, antifungal, antiviral, allergenic contact dermatitis, cytotoxic, insecticidal, anti-HIV, superoxide anion radical release, plant growth regulatory, neurotrophic, NO production inhibitory, muscle relaxing, antiobesity, piscicidal and nematocidal activity. Several inedible mushrooms produce spider female pheromones, strong antioxidant, or cytotoxic compounds. The present paper concerns with the isolation of terpenoids, aromatic compounds and acetogenins from several bryophytes and inedible fungi and their cytotoxic and antiviral activity.

\section{Key words}

bryophytes, inedible fungi, terpenoids, bis-bibenzyls; cytotoxicity, antiviral activity

\section{CHEMICAL CONSTITUENTS OF BRYOPHYTES}

\subsection{Introduction}

The bryophytes are found everywhere in the world except in the sea. They grow on wet soil or rock, the trunk of trees, in lake, river and even in Antarctic island. The bryophytes are placed taxonomically between algae (Fig. 1) and pteridophytes (Fig. 2); there are approximately 24,000 species in the world. They are further divided into three phyla, Bryophyta (mosses 14,000 species, Fig. 3), Marchantiophyta (liverworts 6,000 species, Fig. 4a, 4b) and Anthocerotophyta (hornworts 300 species, Fig. 5). Although they are considered to be the oldest terrestrial plants, no strong scientific evidence for this has appeared in literatures. This hypothesis is mainly based on the resemblance of the present-day liverworts to the first land plant fossils, the spores of which date back almost 500 million years. Among the bryophytes almost

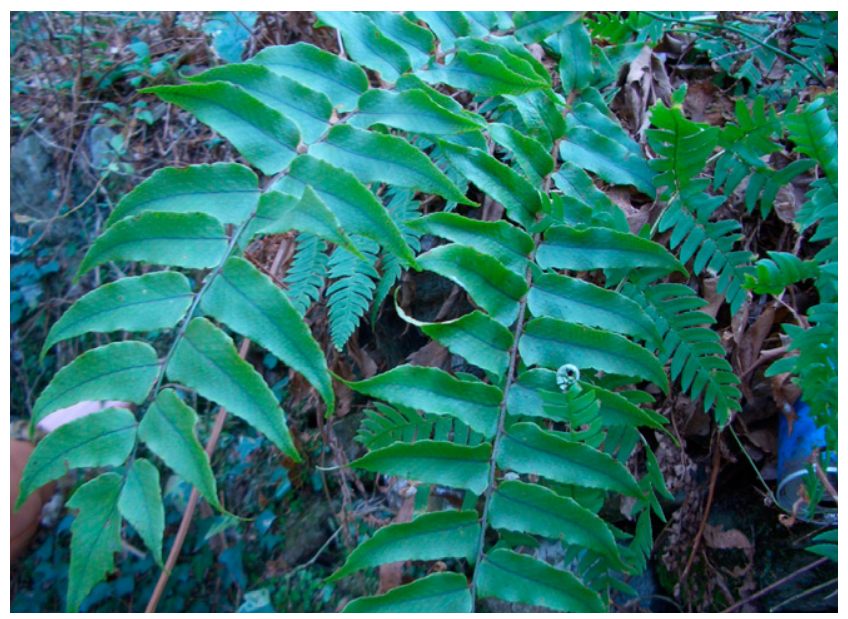

Figure 2. Fern

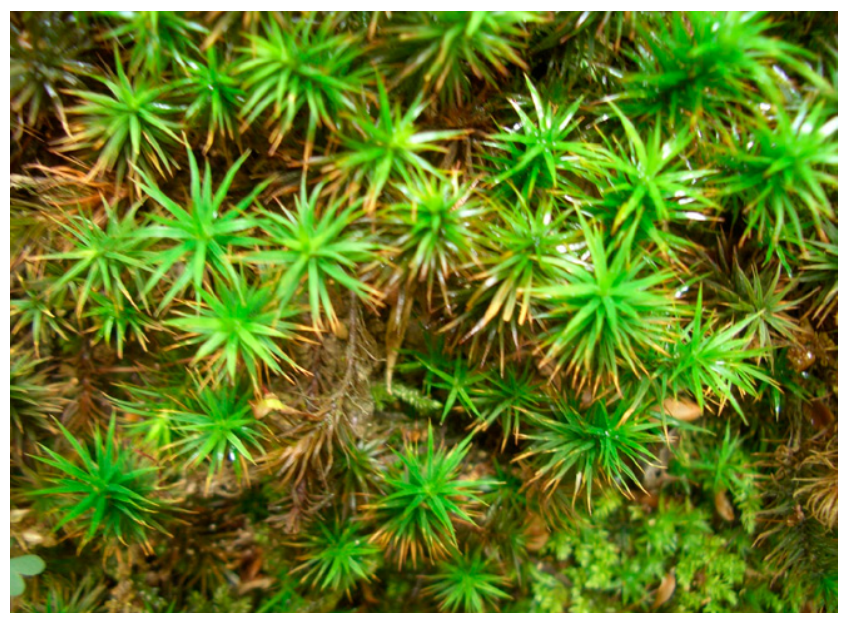

Figure 3. Moss

all liverworts possess beautiful cellular oil bodies (Fig. 6) which are peculiar membrane-bound cell organelles that consist of ethereal terpenoids and aromatic oils suspended

Address for correspondence: Yoshinori Asakawa, Faculty of Pharmaceutical Sciences, Tokushima Bunri University, Yamashiro-cho, Tokushima, Japan e-mail: asakawa@ph.bunri-u.ac.jp

Received: 01 August 2013; accepted: 30 December 2013 


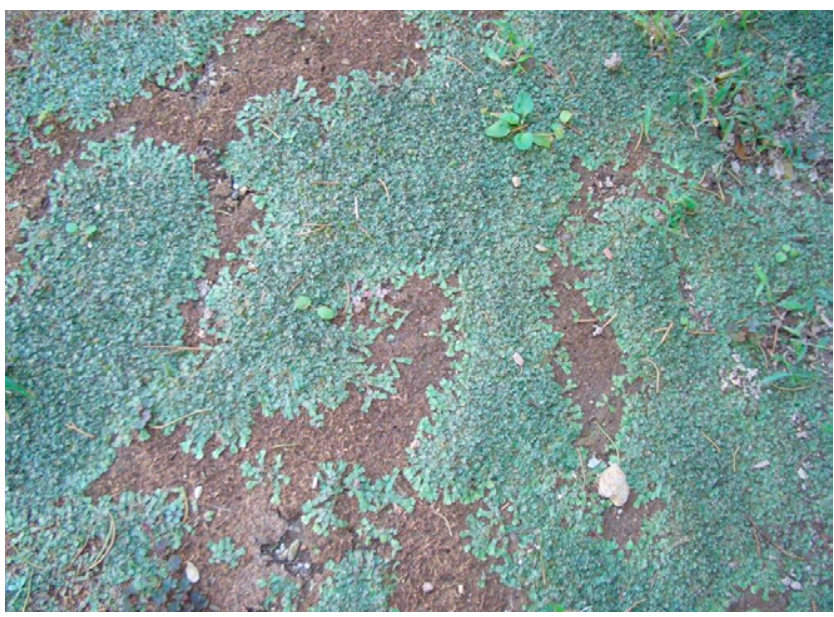

Figure 4a. Thalloid liverwort.

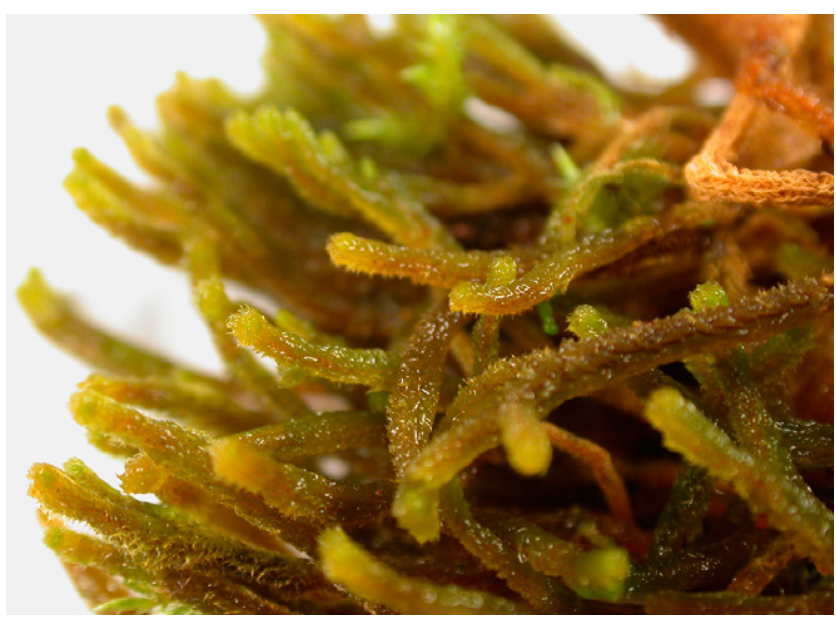

Figure 4b. Stem-leafy liverwort.

in carbohydrates- or protein-rich matrix, while the other two phyla do not. These oil bodies are very important biological marker for the taxonomy in the Marchantiophyta [1-8]. Phytochemistry of bryophytes has been neglected for a long time because they are morphologically very small and difficult to collect a large amount as pure sample, their identification is also very difficult even under the microscope. They are considered to be nutritionally useless to humans. In fact, nothing references concerning use as foods for humans have been seen. However, a number of bryophytes, especially, mosses have been widely used as medicinal plants in China, to cure burns, bruises, external wounds, snake bite, pulmonary tuberculosis, neurasthenia, fractures, convulsions, scald, uropathy, pneumonia, neurasthenia etc. as shown in Table 1 [9-11].

Many species of liverworts show characteristic fragrant odors and an intense pungent, sweet or bitter taste. Generally, bryophytes are not damaged by bacteria and fungi, insect larvae and adults, snails, slugs and other small mammals. Furthermore, some liverworts cause intense allergenic contact dermatitis and allelopathy. Although liverworts possess such pharmacologically interesting substances, their isolation and the structural elucidation were neglected for almost one century.

The paper concerns with the cytotoxic and antiviral activity of terpenoids, aromatic compounds and acetogenins from bryophytes $[2-4,8,12,13]$.

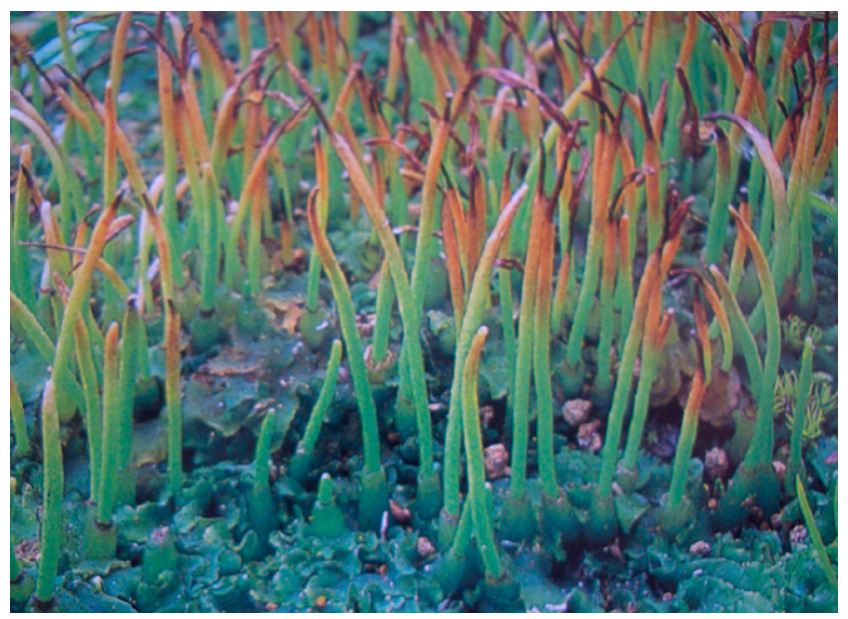

Figure 5. Hornwort

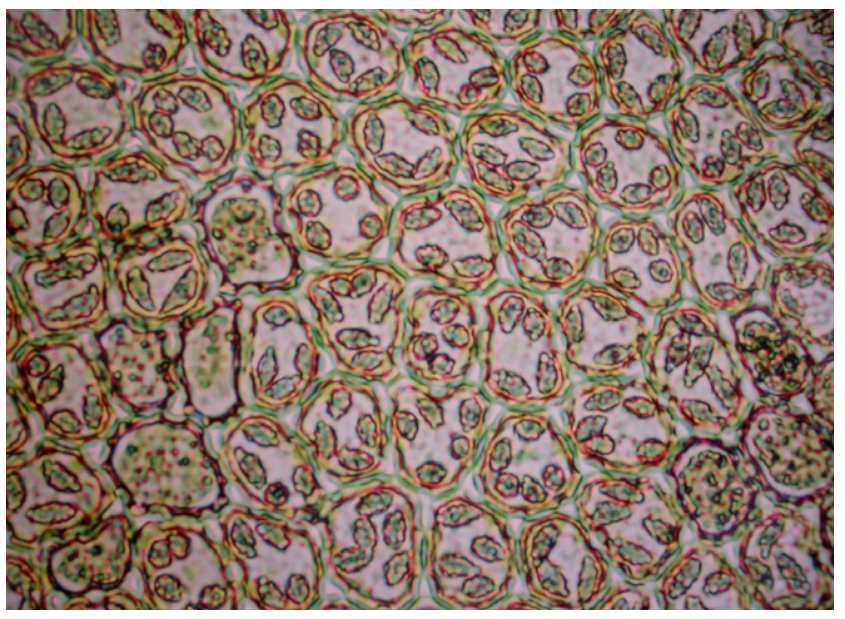

Figure 6. Oil bodies of the liverwort Frullania vethii

\subsection{Bio- and Chemical Diversity of Bryophytes \\ 1.2.1 Biodiversity of bryophytes}

The Marchantiophyta includes two subclasses, the Jungermanniidae and Marchantiidae, and six orders, 49 families, 130 genera and 6,000 species. Still many new species have been recorded in the literatures. The southern hemisphere together with tropic region is characterized by extraordinarily high liverwort diversity [14]. This area has more endemic liverwort species than the northern hemisphere. As seen in Fig. 7, there are 54 endemic genera in southern hemispheric countries, such as New Zealand and Argentina [15]. In Asia including Japan, relatively large number of endemic genera (21) also has been recorded, however, South Africa, Madagascar and both North America and Europe are very poor regions of endemic liverworts. The richness of endemic genera of bryophytes in southern hemisphere suggests that the bryophytes might originate from the past Antarctic islands since 350 - 400 million years ago and developed to the northern hemisphere with a long range evolutionary process. In Japan, Yaku Island is the most important place to watch many species of the Marchantiophyta. In the southern hemisphere, New Zealand is the most charming country to see many different species of the Marchantiophyta which are totally different from those found in the northern Asia, including Japan.

In the tropical regions, such as south-east Asia, Borneo, Sumatra and Papua New Guinea and Colombia, Ecuador and Venezuela, there are rain forests where so many liverworts 
Table 1. Medicinal bryophytes and their biological activity and effects

\begin{tabular}{|c|c|}
\hline Musci: & Biological activity and effects \\
\hline Bryum argenteum & Antidotal, antipyretic, antirhinitic activity; for bacteriosis \\
\hline Cratoneuron filicinum & For malum cordis (heart disease) \\
\hline Ditrichum pallidum & For convulsions, particularly in infants \\
\hline Fissidens japonicum & Diuretic activity; for growth of hair, burns, and choloplania (jaundice, icterus) \\
\hline Funaria hygrometrica & $\begin{array}{l}\text { For hemostatis, pulmonary tuberculosis, vomitus cruentus (hematemesis), bruises, and athlete's foot dermatophytosis (dermatomycosis, } \\
\text { dermomycosis) }\end{array}$ \\
\hline Haplocladium catillatum & Antidotal, and antipyretic activity; for adenopharyngitis, pharyngitis, uropathy, mastitis, erysipelas (rose), pneumonia, urocystitis, and tympanitis \\
\hline Leptodictyum riparium & Antipyretic; for choloplania, and uropathy \\
\hline Mnium cuspidatum & For hematostasis and nosebleed \\
\hline Oreas martiana & For anodyne (pain), hemostasis, external wounds, epilepsy, menorrhagia, and neurasthenia (nervosism, nervous exhaustion) \\
\hline Philonotis fontana & Antipyretic, antidotal activity; for adenopharyngitis \\
\hline Plagiopus oederi & As a sedative; for epilepsy, apoplexy, and cardiopathy \\
\hline Polytrichum species & Diuretic activity; for hair growth \\
\hline Polytrichum commune & Antipyretic, and antidotal; for hemostasis, cuts, bleeding from gingivae, hematemesis, and pulmonary tuberculosis \\
\hline Rhodobryum giganteum & Antipyretic, diuretic, andantihypertensive; for sedation, neurasthenia, psychosis, cuts, cardiopathy, and expansion of heart blood vessels \\
\hline Rhodobryum roseum & As a sedative; for neurasthenia, and cardiopathy \\
\hline Taxiphyllum taxirameum & Antiphlogistic; for hemostasis, and external wounds \\
\hline Weissia viridula & Antipyretic, and antidotal; for rhinitis \\
\hline Hepaticae: & Biological activity and effects \\
\hline Conocephalum conicum & $\begin{array}{l}\text { Antimicrobial, antifungal, antipyretic, antidotal activity; used to cure cuts, burns, scalds, fractures, swollen tissue, poisonous snake bites, and } \\
\text { gallstones }\end{array}$ \\
\hline Frullania tamarisci & Antiseptic activity \\
\hline Marchantia polymorpha & Antipyretic, antihepatic, antidotal, diuretic activity; used to cure cuts, fractures, poisonous snake bites, burns, scalds, and open wounds \\
\hline Reboulia hemisphaerica & For blotches, hemostasis, external wounds, and bruises \\
\hline
\end{tabular}

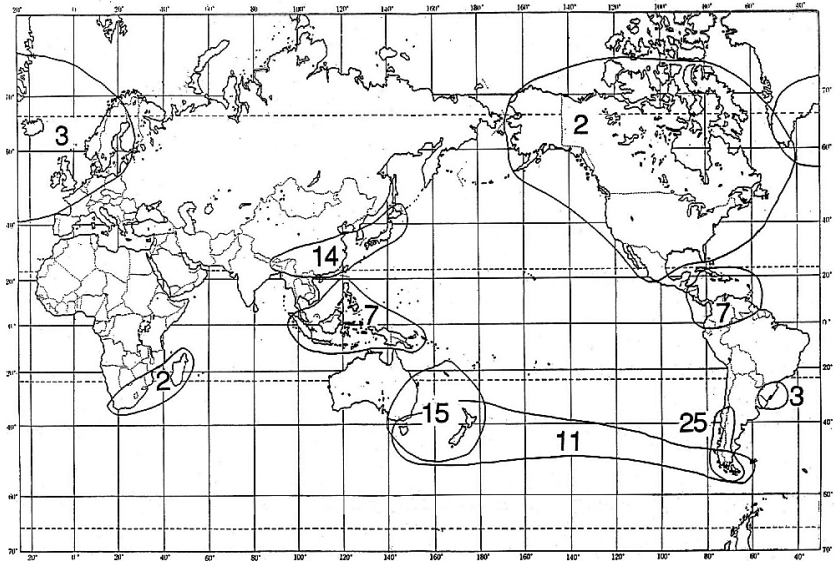

Figure 7. The distribution of endemic liverwort genera

species have been found, but many different species like the Lejeuneaceae species are intermingled each other and thus it is thus time consuming work to purify all of them. In Ecuador and Columbia, the Marchantiophyta species grow in the high mountains, over 2,000m where people live, not in the lower level of their lands.

\subsubsection{Chemical Diversity of Bryophytes}

The extraction of oil bodies with $n$-hexane or ether, using ultrasonic apparatus is very easy for stem-leafy liverworts to give a large amount of crude extract. In case of thalloid liverworts, the specimens are ground mechanically and then extracted with non-polar solvents. At present, over several hundred new compounds have been isolated from bryophytes and their structures were elucidated [2, 3, 4]. Most of compounds found in liverworts are composed of lipophilic mono-, sesqui- and diterpenoids and aromatic compounds, such as typical bibenzyls and bis-bibenzyls.

The most characteristic chemical phenomenon of liverworts is that most of sesqui- and diterpenoids are enantiomers of those found in higher plants although there are a few exceptions such as germacrane- and guaiane-type sesquiterpenoids. It is very noteworthy that the different species of the same genera, like Frullania tamarisci and $F$. dilatata (Frullaniaceae) each produces different sesquiterpene lactone enatiomers. Some liverworts, such as Lepidozia species (Lepidoziaceae), biosynthesize both enantiomers. Flavonoids, fatty acids and phytosterols are ubiquitous components in bryophytes and have been isolated from or detected both in liverworts and mosses.

However, the presence of nitrogen or sulfur or nitrogen and sulfur containing compounds in bryophytes was very rare. Recently several nitrogen-sulfur containing compounds (1-4) have been isolated from the Mediterranean liverwort,

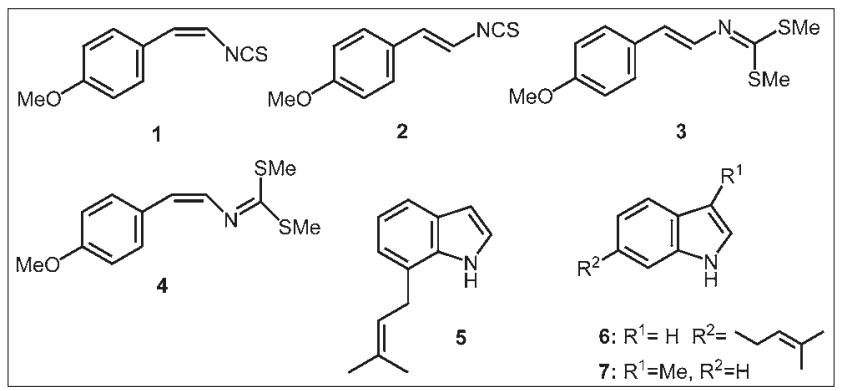


Corsinia coriandrina (Corsiniaceae: Marchantiales) [16], two prenyl indole derivatives $(\mathbf{5 , 6})$ from the Riccardia species (Aneuraceae) [3], skatole (7) from the Asterella or Mannia (Aytoniaceae) [3] and the Tahitian Cyathodium foetidissimum (Cyathodiaceae) [8] and benzyl- $(\mathbf{8 , 9})$ and $\beta$-phenethyl $\beta$-methylthioacrylates (10) from the Isotachidaceae [3].<smiles>[R]c1ccccc1COC(=O)/C=C/SC</smiles>

8: $\mathrm{R}=\mathrm{H}$ 9: $\mathrm{R}=\mathrm{OMe}$

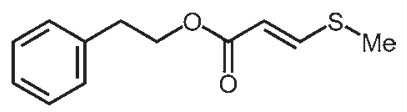

10
Highly evolved liverworts belonging to the Marchantiaceae produce phytosterols, such as campe-, stigma- and sitosterols. Almost all liverworts elaborate $\alpha$-tocopherol and squalene. The characteristic components of the Bryophyta are highly unsaturated fatty acids and alkanones, such as 5,8,11,14,17-eicosapentaenoic acid, 7,10,13,16,19-docosapentaenoic acid and 10,13,16-nonadecatrien-7-yn-2-one and triterpenoids. The neolignan is one of the most important chemical markers of the Anthocerotophyta [3].

The presence of hydrophobic terpenoids is very rare in the Marchantiophyta. A few bitter kaurene glycosides have been found in the Jungermannia species. However a numbers of flavonoid glycosides have been detected both in liverwort and mosses $[2,3,4]$.

\subsection{Bioactive compounds from bryophytes}

The biological characteristics of the terpenoids and aromatic compounds isolated from the liverworts in our laboratory are: 1) characteristic scents, 2) pungency and bitterness, 3) allergenic contact dermatitis, 4) cytotoxic, 5) antimicrobial, antifungal and antiviral, 6) insect antifeedant, mortality, and nematocidal, 7) superoxide anion radical release inhibitory, 8) 5-lipoxygenase, calmodulin, hyaluronidase, cyclooxygenase, DNA polymerase $\beta$ and $\alpha$-glucosidase inhibitory, 9) antioxidant 10) piscicidal 11) neurotrophic, 12) muscle relaxing and calcium inhibitory, 13) cardiotonic and vasopressin antagonist, 14) liver X-receptor (LXR) $\alpha$ agonist and LXR $\beta$ antagonist, 15) cathepsins B and L inhibitory, antithrombin, 16) farnesoid X-receptor (FXR) activation, 17) nitric oxide production inhibitory, 18) plant growth inhibitory, 19) tublin polymerization inhibitory, 20) sex pheromones and 21) antiplatelet and brine shrimp lethal activity.

\subsubsection{Cytotoxic compounds from bryophytes}

Several sesquiterpene lactones, such as eudesmanolides, germacranolides, and guaianolides isolated from liverworts exhibit cytotoxic activity against KB nasopharyngeal and P-388 lymphocytic leukemia cells (Asakawa 1995). The crude ether extracts of the liverworts Bazzania pompeana, Kurzia makinoana, Lophocolea heterophylla, Makinoa crispata, Marsupella emarginata, Pellia endiviifolia, Plagiochila fruticosa, P. ovalifolia, Porella caespitans, P. japonica, $P$. perrottetiana, $P$. vernicosa, and Radula perrottetii showed cytotoxicity against $\mathrm{P}-388$ cells $\left(\mathrm{IC}_{50}\right.$ value range 4-20 $\mu \mathrm{g} / \mathrm{mL}$ ). In contrast, the crude extracts of Frullania diversitexta, F. ericoides, F. muscicola, F. tamarisci subsp. obscura, Lepidozia vitrea, Pallavicinia subciliata, Plagiochila sciophila, Spruceanthus semirepandus, and Trocholejeunea sandvicensis were inactive against this same cell line ( $\mathrm{IC}_{50}$ values $>20 \mu \mathrm{g} / \mathrm{ml}$ ) (Asakawa, unpublished results).

Many Plagiochila species contained cytotoxic plagiochiline A (11) $(0.28 \mu \mathrm{g} / \mathrm{mL})$ against KB cell [12]. The ether extract of Plagiochila ovalifolia showed inhibitory activity against P-388 murine leukemia cells, and its constituents, plagiochiline A (11), plagiochiline A-15-yl octanoate (12), and 14-hydroxyplagiochiline A-15-yl $(2 E, 4 E)$-dodecadienoate (13) exhibited $I C_{50}$ values of $3.0,0.05$, and $0.05 \mu \mathrm{g} / \mathrm{mL}$, respectively [17]. Compound 12 and plagiochiline A-15-yl decanoate (14) from P. ovalifolia, polygodial (15) from P. vernicosa complex, as well as sacculatal (16) from $P$. endivifolia showed cytotoxic activity against a human melanoma cell line $\left(\mathrm{IC}_{50}\right.$ value range $2-4 \mu \mathrm{g} / \mathrm{mL}$ ). Compound 16 was cytotoxic also for Lul ( $\mathrm{IC}_{50} 5.7 \mu \mathrm{g} / \mathrm{mL}$ ), $\mathrm{KB}$ (3.2), LNCaP (7.6), and ZR75-1 cells (7.6) (Cordell, Pezzuto, Asakawa, unpublished results). Lepidozenolide (17) showed potent cytotoxicity when evaluated in the $\mathrm{P}-388$ murine leukemia cell line $\left(\mathrm{IC}_{50}\right.$ $2.1 \mu \mathrm{g} / \mathrm{mL}$ ) [18].

$2 \alpha, 5 \beta$-Dihydroxybornane-2-cinnamate (18) from Conocephalum conicum and lunularin (19) from Dumortiera hirsuta, exhibited cytotoxic activity against human HepG2 cells, with $I C_{50}$ values of 4.5 and $7.4 \mu \mathrm{g} / \mathrm{mL}$ respectively [19].

Chandonanthus hirtellus produces a new sesquiterpene lactone, chandolide (20) [20], 13,18,20-tri-epichandonanthone (21) [21] and anadensin (22) which were evaluated for cytotoxic activity against the HL-60 leukemia cell line, and exhibited $\mathrm{IC}_{50}$ values, in turn, of 5.3, 18.1, and $17.0 \mu \mathrm{g} / \mathrm{mL}$. $6 \alpha$-Methoxyfusicoauritone (23) isolated from the same liverwort showed some cytotoxicity against $\mathrm{KB}$ cells ( $\mathrm{IC}_{50} 11.2 \mu \mathrm{g} / \mathrm{mL}$ ), although compounds 21 and 22 were inactive [20,22].

13-Hydroxychiloscyphone (24) from Chilosyphus rivularis, was tested against the RS322, RS188N, and RS321 yeast strains. It showed $\mathrm{IC}_{12}$ values of 75 and $88 \mu \mathrm{g} / \mathrm{mL}$ for strains RS321 and RS322. These data are characteristic of a selective DNA-damaging agent that does not act as a topoisomerase I or II inhibitor. Compound $\mathbf{2 4}$ also showed cytotoxic

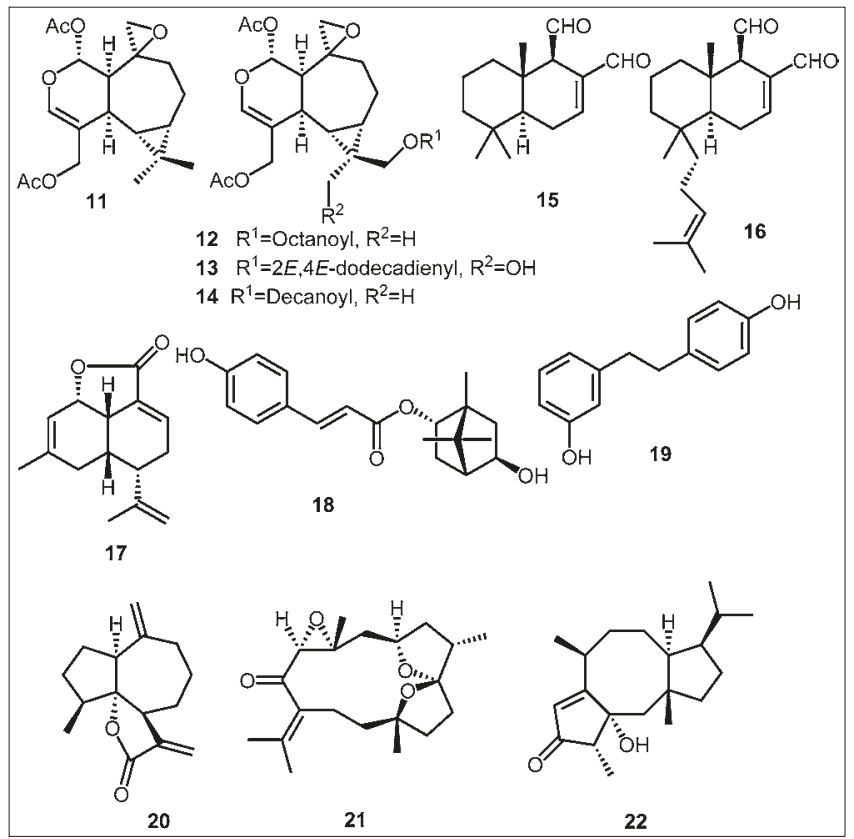




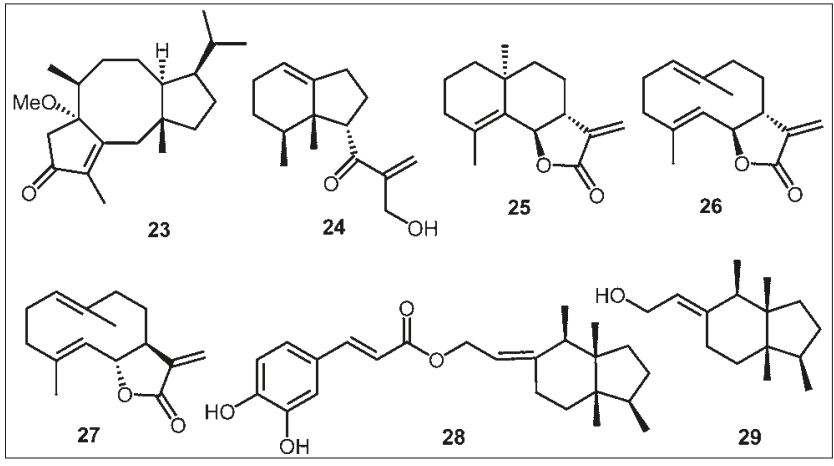

activity against lung carcinoma $\mathrm{A}-549$ cells $\left(\mathrm{IC}_{50}\right.$ value $2.0 \mu \mathrm{g} / \mathrm{mL})$ [23].

(-)-ent-Arbusculin B (25) and (-)-ent-costunolide (26) from Hepatostolonophora paucistipula, showed cytotoxic activity against P388 murine leukemia cells, with $\mathrm{IC}_{50}$ values of 1.1 and $0.7 \mu \mathrm{g} / \mathrm{mL}$ [24]. Costunolide (27) isolated from Frullania nisqualensis showed growth inhibitory activity against the A-549 human lung carcinoma cell line with an $I C_{50}$ value of $12 \mu \mathrm{g} / \mathrm{mL}$ and moderate, but selective, DNA-damaging activity against the RS321N, RS322YK, and RS167K mutant yeast strains, with $\mathrm{IC}_{12}$ values of 50,150 , and $330 \mu \mathrm{g} / \mathrm{mL}$ [25]. Naviculyl caffeate (28), from Bazzania novae-zelandiae, demonstrated growth inhibitory effects against P-388 murine leukemia cells with a $G I_{50}$ value of $0.8-1.1 \mu \mathrm{g} / \mathrm{mL}$, although naviculol (29) was inactive [26]. Riccardiphenol C (30), from Riccardia crassa showed slight cytotoxicity against BSC-1 (African green monkey kidney epithelial) cells at $60 \mu \mathrm{g} /$ disk [27].

The ether and methanol extracts of the Tahitian Mastigophora diclados showed cytotoxic activity against HL 60 cells at $\mathrm{IC}_{50} 2.4$ and $13.1 \mu \mathrm{g} / \mathrm{mL}$ and $\mathrm{KB}$ cells at 14.6 and $32.5 \mu \mathrm{g} / \mathrm{mL}$, respectively [28]. (-)-Diplophyllolide (31), $\alpha$-herbertenol (32), (-)-herbertene-1,2-diol (33), mastigophorene C (34) and mastigophorene D (35) isolated from both extracts were cytotoxic against HL 60 cells with $\mathrm{IC}_{50}$ values of $2.5,1.4,12.8,1.4$, and $2.4 \mu \mathrm{g} / \mathrm{mL}$. They also showed cytotoxicity against $\mathrm{KB}$ cells ( $\mathrm{IC}_{50}$ values of $14.2,3.3$, $12.5,11.8$ and $14.8 \mu \mathrm{g} / \mathrm{mL})$. 2-Methoxy (36) and diacetoxy derivatives (37) of herbertane-1,2-diol (33) showed evidence of having less potent cytotoxicity than the parent compound

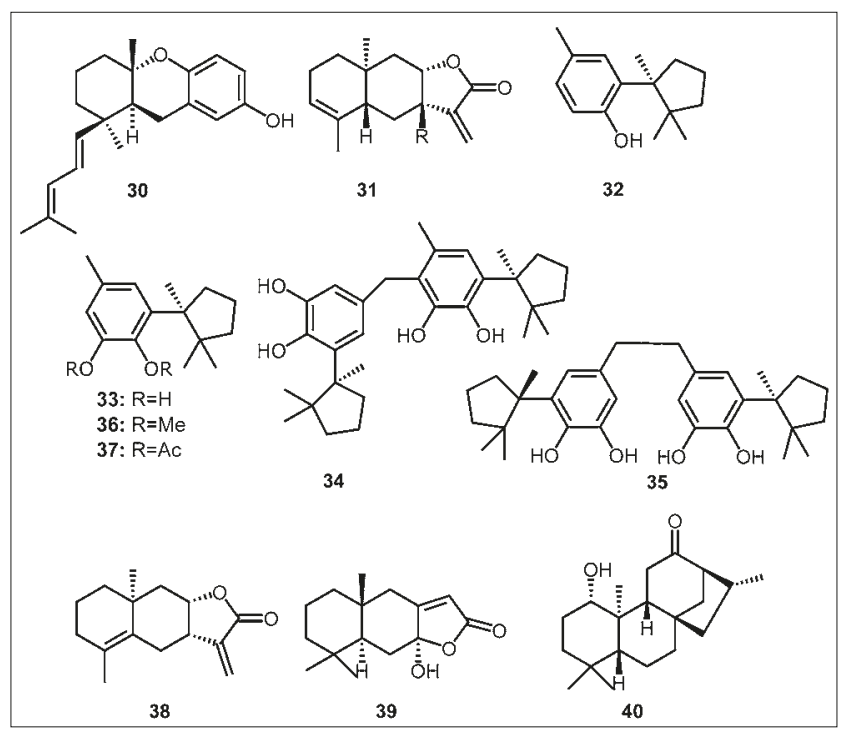

against both HL 60 and KB cells. However, (-)-diplophyllin (38) did not indicate cytotoxicity against either of these cell lines [28].

Glaucescenolide (39) from Schistochila glaucescens showed cytotoxic activity against P-388 mouse leukemia cells $\left(\mathrm{IC}_{50} 2.3 \mu \mathrm{g} / \mathrm{mL}\right.$ ) [29]. ent-1 $\beta$-Hydroxykauran-12-one (40), isolated from Paraschistochila pinnatifolia and $1 \alpha$-hydroxyent-sandaracopimara-8(14),15-diene (41) from Trichocolea mollissima, showed $\mathrm{IC}_{50}$ values of 15 and $>25 \mu \mathrm{g} / \mathrm{mL}$, when evaluated against this same cell line [30].

The ethanol-soluble extract of Lepidolaena taylorii which showed cytotoxicity against $\mathrm{P}-388$ cell line, $\left(\mathrm{IC}_{50} 1.3 \mu \mathrm{g} / \mathrm{mL}\right)$, was purified to give the 8,9 -secokaurane diterpenoids, rabdoumbrosanin (43), 16,17-dihydrorabdoumbrosanin (43), 8,14-epoxyrabdoumbrosanin (44) and their related compounds 45-48 and the ent-kaur-16-en-15-ones (49-53). In turn, L. palpebrifolia also elaborated the 8,9-secokauranes $(42,44)$. The cytotoxicity of these ent-8,9-seco and entkaurenes was tested against the mouse P-388 leukemia and several human tumor cell lines, inclusive of six leukemia and a range of organ-specific cancer cell lines. Compounds $\mathbf{4 2}$ and $\mathbf{4 4}$ showed the most potent cytotoxic activities (mean $\mathrm{IC}_{50}$ values of 0.006 and $0.27 \mu \mathrm{g} / \mathrm{mL}$; $\mathrm{GI}_{50}$ values of 0.10 and $1.2 \mu M$, respectively). Compound 44 also showed cytotoxicity against P-388 cell at $0.80 \mu M$.). Compounds 42 (including $10 \%$ of 43 ) and 44 showed differential cytotoxicity in vitro when tested against five further leukemia cell lines with $\mathbf{4 1}$ showing an average $\mathrm{IC}_{50}$ value of $0.4 \mu \mathrm{M}$; however, cell growth was not inhibited by $\mathbf{4 4}\left(\mathrm{IC}_{50}>50 \mu M\right)$. The growth of seven colon cancer cell lines was inhibited also by 42 (mean IC $_{50}$ value, $6 \mu M$ ) [31,32]. Compounds 42 and 44 were tested in an in vivo hollow fiber model system, in which neither compound was active at the doses tested ( 18 and $12 \mu \mathrm{g} / \mathrm{kg}$ for 42 and 150 and $100 \mu \mathrm{g} / \mathrm{kg}$ for 44). Compound 48 was most active against several leukemia cell lines (mean $G I_{50} 0.3 \mu M$ ) and least active against various central nervous system cancer cell lines (mean $\mathrm{GI}_{50} 6 \mu \mathrm{M}$ ) [32].

Ent-kaurene (54) and (55) from the New Zealand Jungermannia species showed weak cytotoxic activity against P-388 at 0.48 and $25 \mu \mathrm{g} / \mathrm{mL}$, respectively [33] Among the isolated compounds, 8,9-secokaurenes $(\mathbf{4 2}, 44,48)$ showed selective toxicity amongst human tumor cell lines at a concentration of $1.2,2.5$ and $1.5 \mu \mathrm{M}$, respectively.
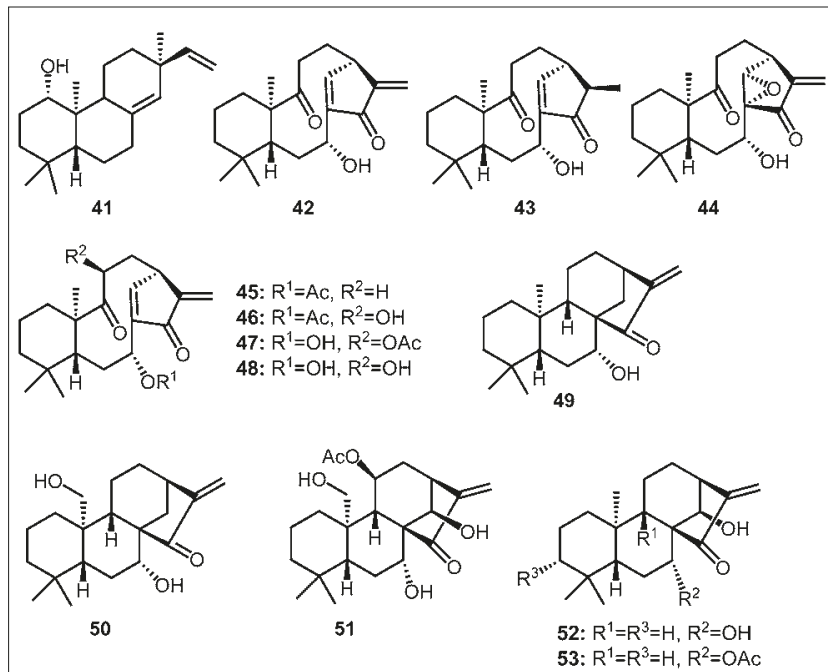
The mode of action for the cytotoxicity of the ent-8,9secokaur-16-en-15-one and ent-kaur-16-en-15-one series was supported by Michael addition of a thiol to the C-16-C-17 double bond of 42 , but the C-8-C-14 double bond of 43 was relatively unreactive [31,32].

Clavigerins A-D (56-59) isolated from Lepidolaena clavigera showed a weak cytotoxicity $(30 \mu \mathrm{g} / \mathrm{disk})$ against BSC cells [34].

A new atisane-2 derivative (60) from Lepidolaena clavigera exhibited weak inhibitory activity against mouse lymphocytic leukemia cells (P-388) with an $\mathrm{IC}_{50}$ value of $16 \mu \mathrm{g} / \mathrm{mL}$ [35] [35]. $\alpha$-Zeorin (61) has been isolated from several liverworts and displayed cytotoxic activity against P-388 cells with an $\mathrm{IC}_{50}$ of $1.1 \mu \mathrm{g} / \mathrm{ml}[36,37]$.

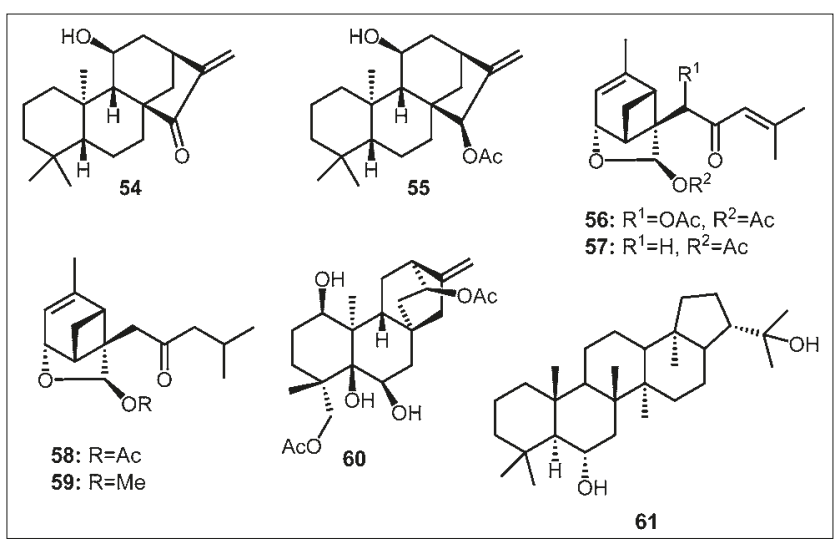

The crude ether extract of two unidentified Indonesian and Tahitian Frullania species exhibited cytotoxic activity against both the HL-60 and $\mathrm{KB}$ cell lines, with at $E C_{50}$ values of 6.7 and $1.6 \mu \mathrm{g} / \mathrm{mL}$ (HL-60 cells) and 1.6 and $11.2 \mu \mathrm{g} / \mathrm{mL}$ (KB cells), respectively [38]. Bioactivity-guided fractionation of the Indonesian sample led to the isolation of (+)-3 $\alpha$-(4'-methoxybenzyl)-5,7-dimethoxyphthalide (62), (-)-3 $\alpha$-(3'-methoxy-4',5'-methylenedioxybenzyl)-5,7dimethoxyphthalide (63), together with 3-methoxy-3',4'methylenedioxybibenzyl (64), 2,3,5-trimethoxy-9,10dihydrophenanthrene (65) and atranorin (66), among which

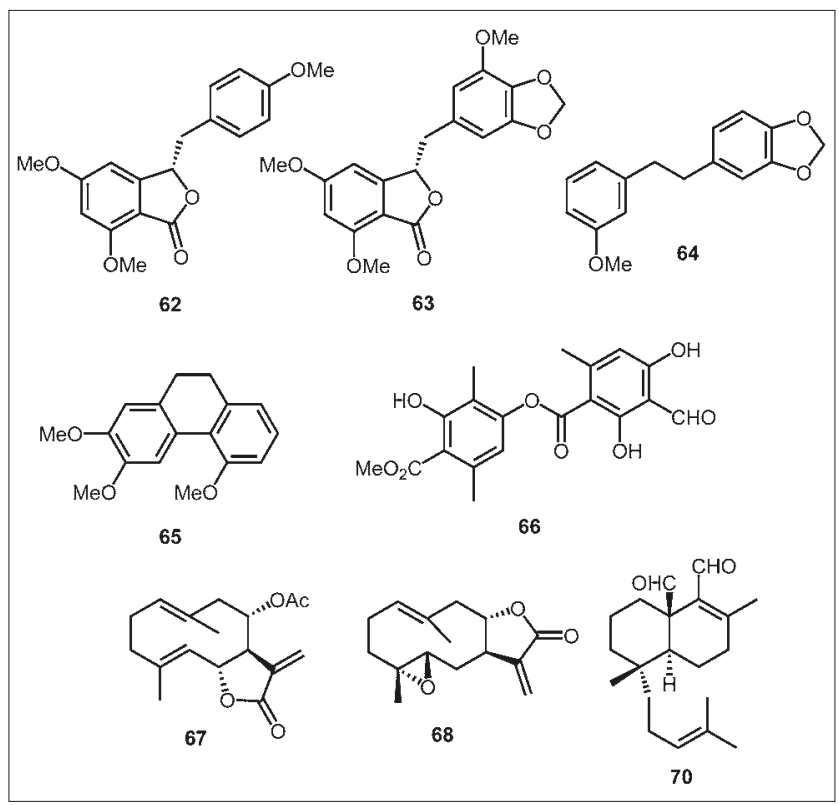

61 possessed the most potent cytotoxic activity against HL60 and $\mathrm{KB}$ cells showing $\mathrm{IC}_{50}$ values of 0.92 and $0.96 \mu \mathrm{M}$. The other compounds (63-65) and the 6'-nitro derivative of 63 indicated much less activity against both cell lines (HL-60 IC ${ }_{50}$ value range, 6.3-96.6 $\mu \mathrm{M}$; $\mathrm{KB} \mathrm{IC}_{50}$ value range, 5.5-124.3 $\mu M$ ). From the Tahitian sample, costunolide (27) and tulipinolide (67) were obtained and the former germacranolide shown to be cytotoxic against the HL-60 cell line $\left(\mathrm{IC}_{50} 4.6 \mu \mathrm{M}\right)$ [38].

Porella perrottetiana produced cytotoxic compounds against both HL-60 and KB cell lines [38]. The same treatment as mentioned above gave $4 \alpha, 5 \beta$-epoxy- 8 -epiinunolide (68), 7-keto-8-carbomethoxypinguisenol (69) and perrottetianal A (70). The former two compounds exhibited moderate or weak cytotoxicity against HL-60 ( $\mathrm{IC}_{50} 8.5$ and $2.7 \mu M)$ and $\mathrm{KB}$ cells $\left(\mathrm{IC}_{50} 52.4\right.$ and $\left.46.3 \mu M\right)$. $7 \alpha$-Hydroxy8-carbomethoxypinguisenol (71a) and acutifolone A (71b) prepared from 69 by reduction and dehydration were evaluated against HL-60 ( $\mathrm{IC}_{50} 83.10$ and $\left.>177 \mu \mathrm{M}\right)$ and $\mathrm{KB}$ cells ( $\mathrm{IC}_{50} 2.7$ and $46.6 \mu \mathrm{M}$ ). It was suggested that the dienone group plays an important role in the mediation of cytotoxcity against HL-60 cells [38].

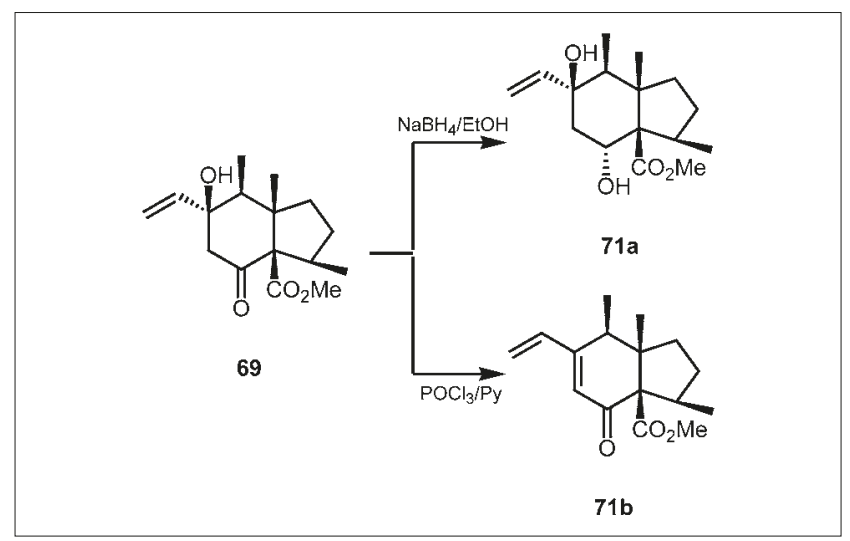

Macrocyclic bis-bibenzyls such as marchantin A (72) and riccardin A (73) were firstly isolated from liverworts by Asakawa et al.[1,2]. Up to now, more than 60 macrocyclic and acyclic bis-bibenzyls have been isolated from many liverworts and their stereostructures established [3,12,39]. The cyclic bis-bibenzyls such as marchantin (e.g.72) and riccardin series (e.g.73) might be biosynthesized from bibenzyls that correspond chemically to dihydrostilbenes [40]. This assumption was proved by feeding experiments using radioactive and ${ }^{13} \mathrm{C}$-labelled precursors, like $\mathrm{L}-[\mathrm{U}$ $\left.{ }^{14} \mathrm{C}\right]$-phenylalanine, $\left[U-{ }^{14} \mathrm{C}\right]$ dihydro-p-coumaric acid, $[2-$ $\left.{ }^{13} \mathrm{C}\right]$ acetate, and $\mathrm{L}-\left[{ }^{13} \mathrm{COOH}\right]$ phenylalanine. Marchantin $\mathrm{C}$ (74) was biosynthesized by coupling of two lunularic acid (80), followed by cytochrome $\mathrm{P}-450$, named marchantin C hydroxylase to afford marchantin A (72) [4].

Macrocyclic bis-bibenzyls biosynthesized by liverworts possess various biological activities, like antimicrobial, antifungal, muscle relaxant, cytotoxicity against KB cells, inhibitory activity against DNA-polymerase $\beta$, cardiovascular activity, anti-HIV, and antitumor activity $[2,3,13]$

The methanol extract (105 g) of a Japanese specimen of $M$. polymorpha was chromatographed over silica gel and Sephadex LH-20 to give the cyclic bis-bibenzyls, marchantin A (72) (30 g), and its analogues, marchantins B (75), C (74), $\mathrm{D}$ (76), E (77), G (78), J (79). The yield of 72 is dependent 


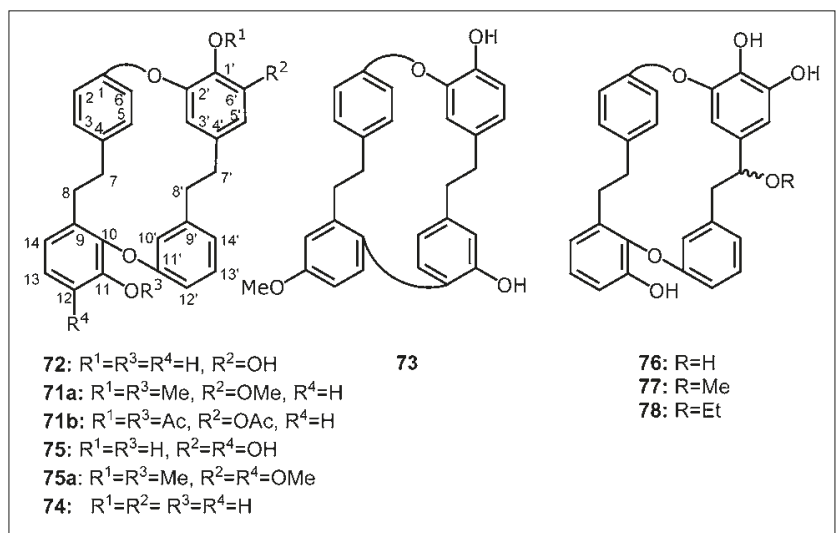

upon the particular Marchantia species being investigated. Pure 72 (80 to $120 \mathrm{~g}$ ) has been isolated from $6.67 \mathrm{~kg}$ of dried M. paleacea var. diptera[4].

This thalloid liverwort elaborates not only the marchantin series, including marchantins A (72), B (75), D (76), and E (77), but also the acyclic bis-bibenzyls, perrottetin $\mathrm{F}(\mathbf{8 1})$ and paleatin B (82). Marchantins A (72), B (75), D (76), perrottetin $\mathrm{F}(\mathbf{8 1})$, and paleatin $\mathrm{B}(\mathbf{8 2})$ showed cytotoxicity against $\mathrm{KB}$ cells $\left(I_{50}\right.$ range 3.7-20 $\mu M$ ) and P-388 (T/C 117) [13].

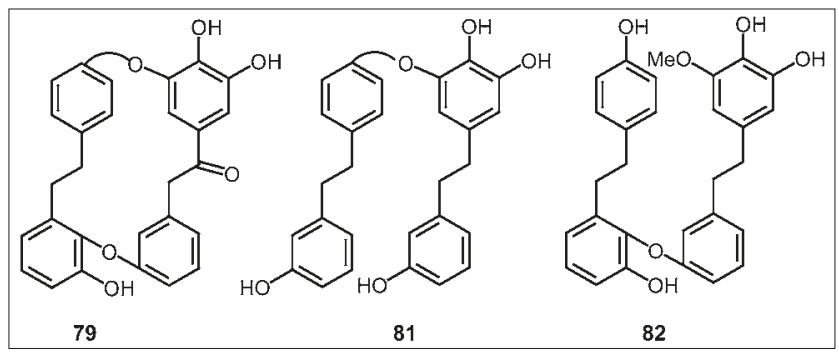

Marchantin A (72) induced cell growth inhibition in human MCF-7 breast cancer cells at $\mathrm{IC}_{50} 4.0 \mu \mathrm{g} / \mathrm{mL}$. Fluorescence microscopic and a Western blot analysis indicated that compound 72 induced apoptosis of MCF-7 cells through a caspase-dependent pathway. The phenolic hydroxy groups at C-1' and C-6' are responsible for inducing cytotoxic and antioxidant activity [41].

Marchantin C (74) and its dimethyl ether, 7,8-dehydromarchantin $\mathrm{C}$ and its dimethyl ether were synthesized and their possible modulatory effects on P-glycoprotein in VCR-resistant KB/VCR cells were investigated [42]. The results indicated that 74 was the most potent inhibitor of cell proliferation in both $\mathrm{KB}$ and $\mathrm{KB} / \mathrm{VCR}$ cells among these four synthetic compounds, while the three derivatives of $\mathbf{7 4}$ has little antiproliferative activity. Potent apoptosis in KB/VCR cells was induced by treatment with $16 \mu M$ of dimethyl ether of marchantin $\mathrm{C}$ (74) and $0.2 \mu M$ VCR for 48 hours [42]. Marchantin C also showed the induction of apoptosis of human glioma A172 cells at 8-16 $\mu M$ [43].

Marchantin C (74), neomarchantins A (83) and B (84), and a mixture of sesquiterpene/bis-bibenzyl dimers, GBB A (85) and GBB B (86) from Schistochila glaucescens showed growth inhibitory activity against the $\mathrm{P}-388$ cell line, with $\mathrm{IC}_{50}$ values of $18,7.6,8.5$, and $10.3 \mu \mathrm{g} / \mathrm{mL}$, respectively [29].

Riccardin D (87) from Monocolea forsteri [3] and Marchantia polymorpha $[44,45]$ indicated antiproliferative activity on human glioma A172 cells and induction of apoptosis at $16 \mu M$. Compound 87 also possesses potent

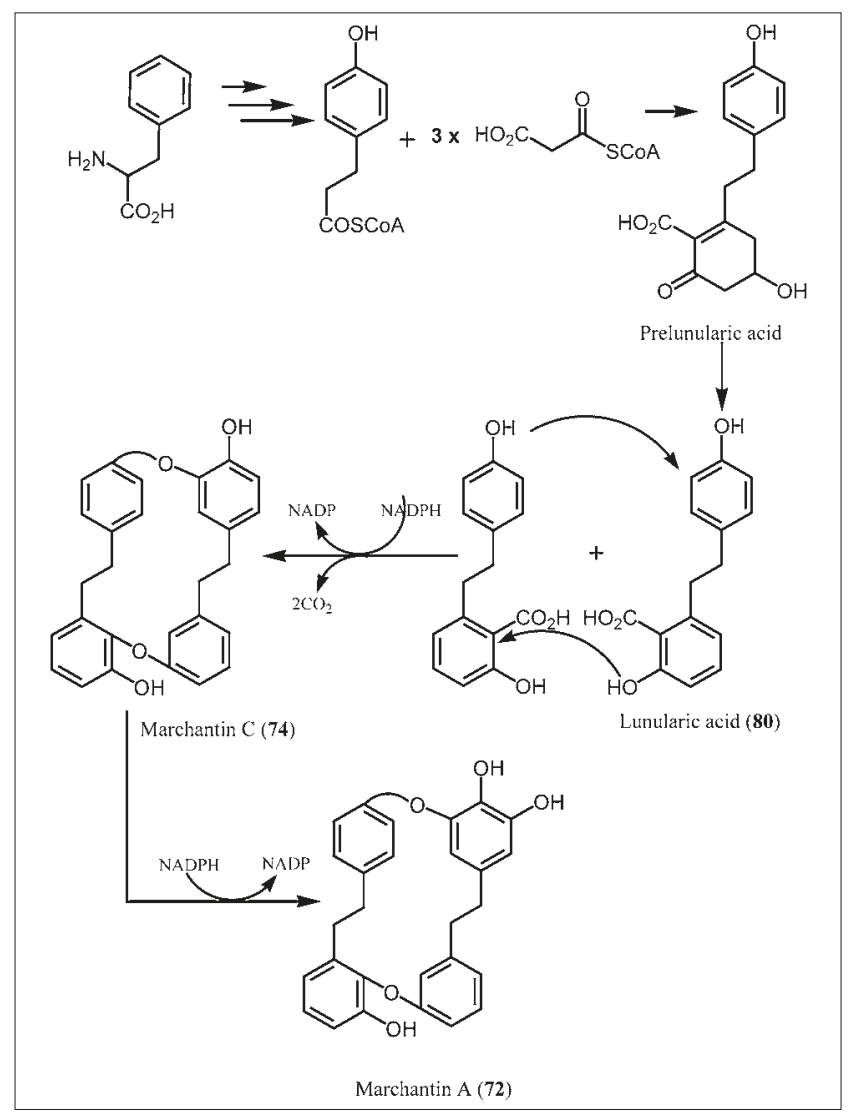

effects in reversing $\mathrm{P}$-glycoprotein-mediated multidrug resistance [44].

2-Hydroxy-3,4,6-trimethoxyacetophenone (88) and 2-hydroxy-4,6-dimethoxyacetophenone (89) from Plagiochila fasciculata, were inactive against the P-388 cell line $\left(\mathrm{IC}_{50}\right.$ values of $>50 \mu \mathrm{g} / \mathrm{mL}$ ) [46].

Trichocolea lanata and T. tomentella produced tomentellin (90), which showed inhibitory activity against African green monkey kidney epithelial (BSC-1) cells at $15 \mu \mathrm{g} / \mathrm{mL}$, with no antiviral effects against herpes simplex or polio viruses. Demethoxytomentellin (91) from $T$. tomentella showed a similar cell growth inhibitory effect, indicating that both an allylic ether and a conjugated enone substructure are required for such activity [47]. Methyl-4-[(2E)-3,7-dimethyl-

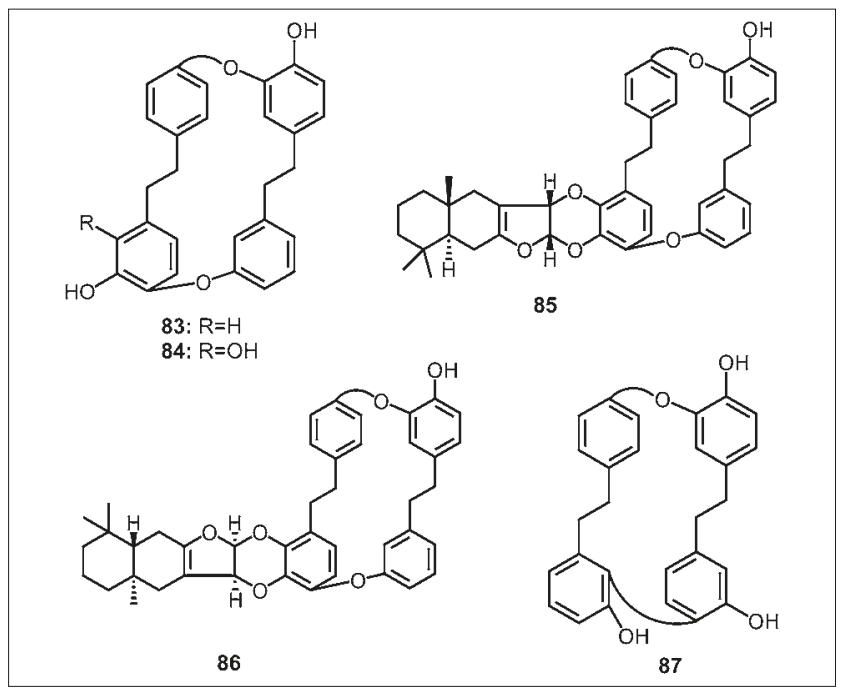


2,6-octadienyl]oxy]3-hydroxybenzoate (92), isolated from T. hatcheri, showed a lack of cytotoxicity $\left(\mathrm{IC}_{50}>100 \mu M\right)$ against both KB and SK-MEL-3 human melanoma cells, as well as NIT 3T3 fibroblasts [48]

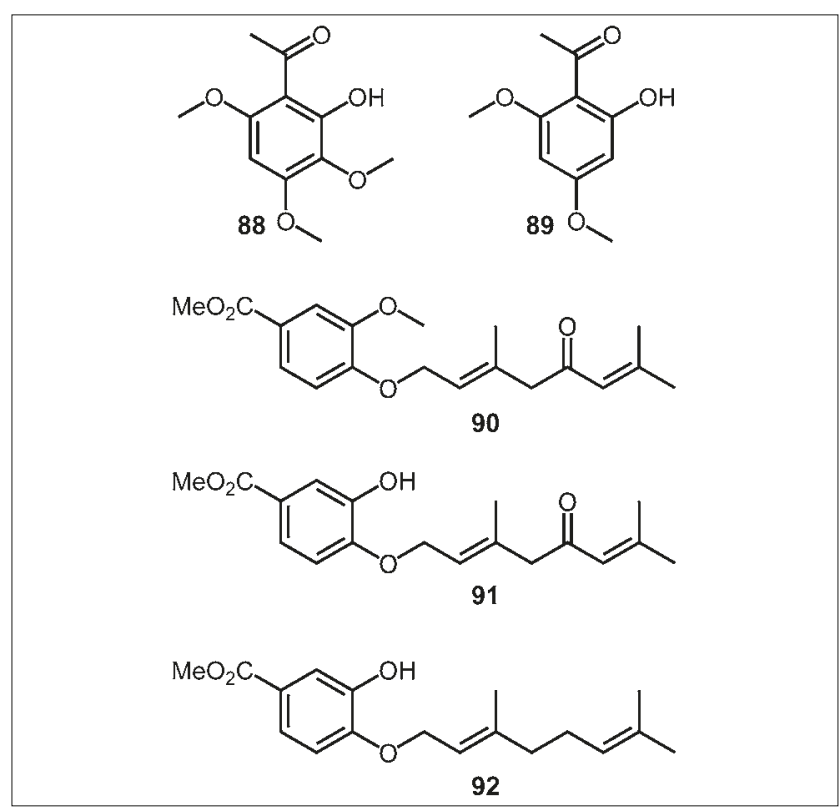

The ent-kauranes and kaurenes $(\mathbf{5 4}, \mathbf{9 3 - 9 5})$ isolated from Jungermannia species inhibited HL- 60 cells with IC $_{50}$ values, in turn, of $0.49,7.0,0.59$, and $0.28 \mu \mathrm{M}$. Treatment of 54 and 93-95 caused proteolysis of poly(ADP-ribose) polymerase, a sign of activation of the apoptotic machinery, whereas the feature of cell death induced by treatment with compounds 93 and 94 was necrosis. Treatment with compound 95 induced apoptosis (see below) [49]. The ent-kaurane diterpenoids 96, 97 and 98-100 from a Jungermannia species showed cytotoxicity for HL-60 cells with $\mathrm{IC}_{50}$ values of $1.00,0.40$, $1.21,1.28$, and $0.78 \mu M$, respectively [50].

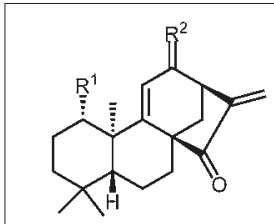

93: $\mathrm{R}^{1}=\mathrm{OH}, \mathrm{R}^{2}=\mathrm{H}, \mathrm{H}$ 94: $R^{1}=H, R^{2}=O$

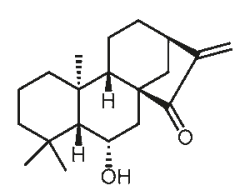

97

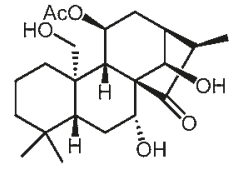

102

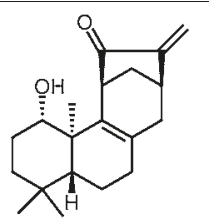

95

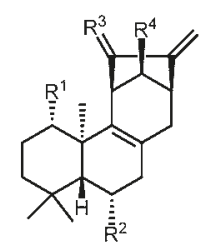

98: $R^{1}=R^{2}=R^{4}=H, R^{3}=O$ 99: $\mathrm{R}^{1}=\mathrm{R}^{2}=\mathrm{H}, \mathrm{R}^{3}=\mathrm{O}, \mathrm{R}^{4}=\mathrm{OH}$ 100: $R^{1}=R^{4}=O H, R^{2}=H, R^{3}=O$

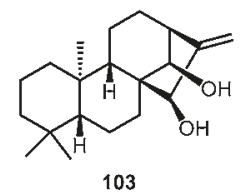

103

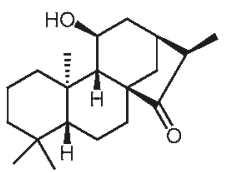

96

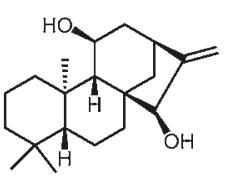

101

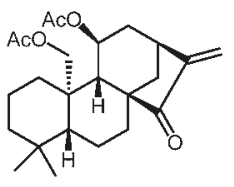

104
The ent-kaurenes 54, 101-106, isolated from the Japanese liverwort Jungermannia truncata, were evaluated for cytotoxicity against HL-60 human leukemia cells. Of these, ent-11 $\alpha$-hydroxy-16-kauren-15-one (54) induced apoptosis (programmed cell death) in this cell line partly through a caspase- 8 dependent pathway $[33,51]$. The presence of an enone group in this class of molecule appears to be essential for the induction of apoptosis and the activation of caspases in human leukemia cell lines [49,52].

ent-Kaurenes 54, 50 and 105 and ent-9(11),16-kauradien12,15-dione (93), and the rearranged ent-kaurene, jungermannenone A (95), selectively inhibited nuclear factor$\mu \mathrm{B}$ (NF- $\mu \mathrm{B})$-dependent gene expression due to treatment with TNF- $\alpha$. Compound 54, in combination with TNF- $\alpha$ caused a dramatic increase in apoptosis in human leukemia cells accompanied by activation of caspases. Compound $\mathbf{5 4}$, when combined with camptothecin, also caused an increase in apoptosis [53,54]. Jungermanenones A-D (95-100), obtained from Jungermannia species, induced cytotoxicity against human leukemia HL-60 cells at 50\% inhibitory concentrations of $1.3,5.5,7.8$, and $2.7 \mu M$, respectively, and DNA fragmentation and nuclear condensation. Both are biochemical markers of apoptosis induction, and apoptosis was induced through a caspase-independent pathway. Compounds 95 and 100 showed inhibitory activity for $\mathrm{NF}-\kappa \mathrm{B}$, which is a transcriptional factor of antiapoptotic factors. Thus, ent-kaurene diterpenoids from liverworts may be promising candidates as antitumor agents $[55,56]$.

Some monoterpenoids, such as bornyl acetate (107) found in liverworts demonstrate potent apoptosisinducing activities against the cultured cells of Marchantia polymorpha. Apoptosis induced by monoterpenoids occurs via the production of active oxygen species such as $\mathrm{H}_{2} \mathrm{O}_{2}$ [57].

The ursane triterpenoids from the liverwort Ptilidium pulcherrimum, ursolic acid (108), acetoxyursolic acid (109), and $2 \alpha, 3 \beta$-dihydroxyurs-12-en-28-oic acid (110) showed inhibition of the growth of PC3 human prostate cancer cells, at concentrations between $10.1 \pm 1.00$ and 39.7 $\pm 2.98 \mu \mathrm{M}$ [58].

Previously, the two pimarane diterpenoids momilactones $A$ (111) and B (112), which were identified as phytoalexins in rice, have been isolated from the moss Hypnum plumaeforme (Hypnaceae) [59]. Momilactone B (112) was shown to have cytotoxicity against human colon cancer HT-29 and SW620 cells at $1 \mu M[60]$.

Pallidisetin A (113) and pallidisetin B (114), isolated from the moss Polytrichum pallidiscetum, showed cytotoxicity against human melanoma (RPMI-7951) and human

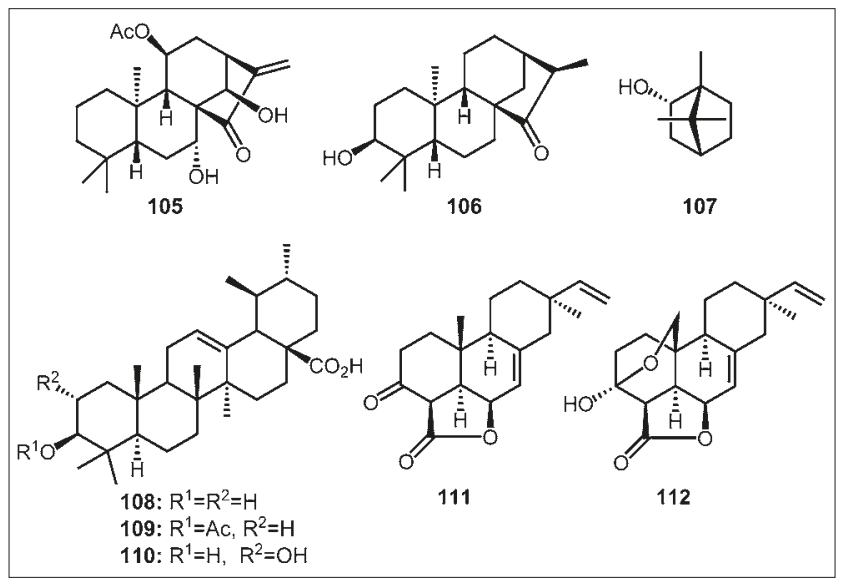




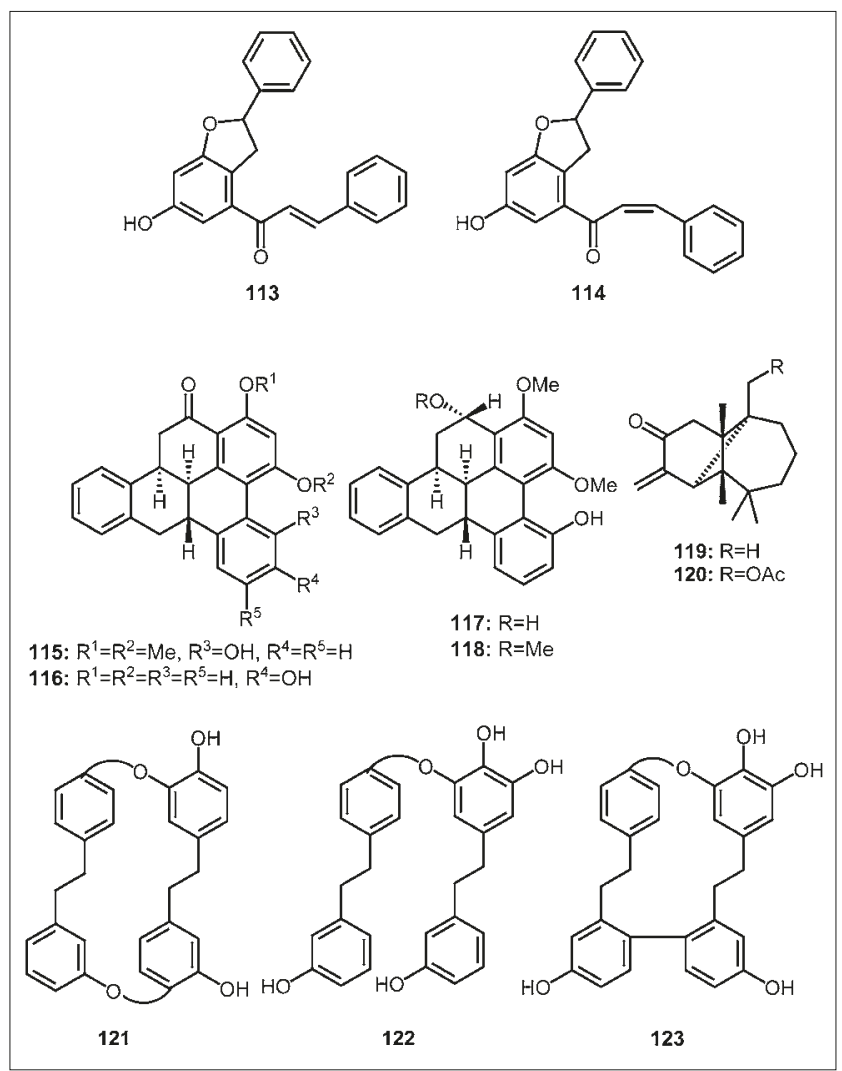

glioblastoma multiforme (U-251 MG) cells, with $E D_{50}$ values of 1.0 and $1.0 \mu \mathrm{g} / \mathrm{mL}$ and 2.0 and $2.0 \mu \mathrm{g} / \mathrm{mL}$ [61].

Three cytotoxic compounds, 1-O-methylohioensin B (115), 1-O-methyldihydroohioensin B (116) and 1,14-di$\mathrm{O}$-methyldihydroohioensin B (118) were also isolated from the moss Polytrichum pallidisetum. Compound 115 proved to be cytotoxic for human colon adenocarcinoma (HT-29), human melanoma (RPMI-7951), and human glioblastoma multiforme (U-251 MG) cells, with $\mathrm{ED}_{50}$ values of 1.0, 1.0, and $2.0 \mu \mathrm{g} / \mathrm{mL}$. Compound $\mathbf{1 1 6}$ showed inhibitory activity only against $\mathrm{U}-251$ cells $\left(\mathrm{ED}_{50} 0.8 \mathrm{mg} / \mathrm{mL}\right)$ while 118 inhibited the growth of the A549 lung carcinoma (A549) $\left(\mathrm{ED}_{50} 1.0 \mu \mathrm{g} / \mathrm{mL}\right.$ ) and RPMI-7951 melanoma $\left(\mathrm{ED}_{50} 1.0 \mu \mathrm{g} / \mathrm{mL}\right)$ cell lines [61]. Ohioensin H (117) from Polytrichum commune did not show any cytotoxicity against the five human cancer cell lines in which it was evaluated ( $\mathrm{IC}_{50}$ in all cases $>5 \mu \mathrm{g} / \mathrm{mL}$ ) [62].

Marsupellone (119) and acetoxymarsupellone (120) from Marsupella emarginata showed cytotoxicity $\left(\mathrm{ID}_{50}\right.$ $1 \mu \mathrm{g} / \mathrm{mL}$ ) against P388 [10]. Riccardins A (73) and B (121) which were the first bis-bibenzyls from the Japanese liverwort, Riccardia multifida subsp. decrescens inhibited $\mathrm{KB}$ cells at a concentration of 10 and $12 \mu \mathrm{g} / \mathrm{mL}$, respectively. Radula perrottetii contained cytotoxic perrottetin E (122) $(12.5 \mu \mathrm{g} / \mathrm{mL})$ against $\mathrm{KB}$ cells [10].

\subsubsection{Antiviral compounds from bryophytes}

Marchantins A (72), B (75), D (76), perrottetin F (81), and paleatin $\mathrm{B}(\mathbf{8 2})$ showed anti-HIV-1 activity $\left(\mathrm{IC}_{50}\right.$ range 5.3$23.7 \mu \mathrm{g} / \mathrm{mL})[10,63]$ as shown in Table 2 .

The H1N1 and $\mathrm{H} 5 \mathrm{~N} 1$ influenza A virus caused pandemics throughout the world in 2009. Influenza A possesses an endonuclease within its RNA polymerase comprised of PA, $\mathrm{PB} 1$, and $\mathrm{PB} 2$ subunits. In order to obtain potential new antiinfluenza compounds, 33 different types of phytochemicals
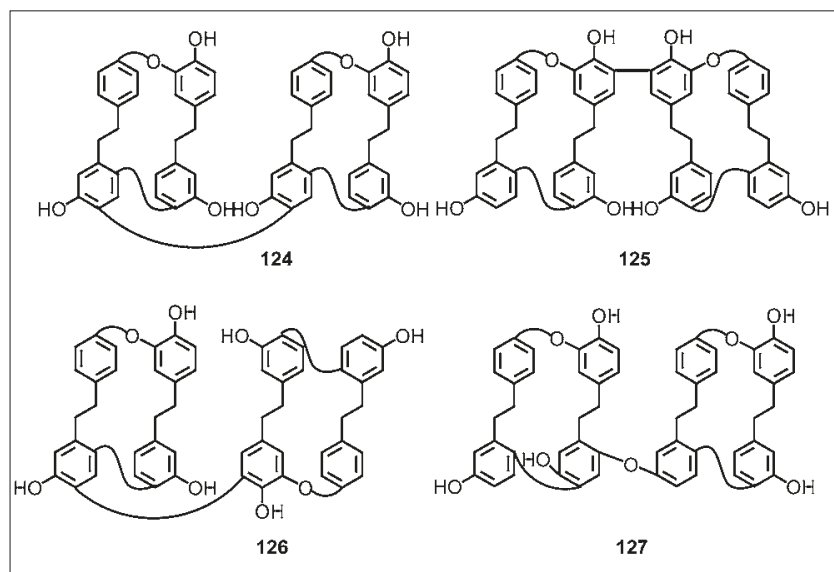

were evaluated using a PA endonuclease inhibition assay in vitro [64]. Among them, the bis-bibenzyls, marchantins A (72), B (75), and E (77) and plagiochin A (123) inhibited influenza PA endonuclease activity at a concentration of $10 \mu M$. This was the first evidence that the phytochemicals derived from liverworts can inhibit influenza A endonuclease.

Blasia pusilla produces the bis-bibenzyl dimers, pusilatins A-D (124-127). Pusilatins B (125) and C (126) were found to possess DNA polymerase $b$ inhibitory activity $\left(I C_{50}\right.$ values of 13.0 and $5.16 \mu M$, respectively) and showed weak HIV-RT inhibitory activity [65] as shown in Table 2.

Table 2. Cytotoxic and anti-viral bis-bibenzyls from bryophytes against KB cells, DNA polymerase $\beta$ and HIV-1

\begin{tabular}{lccccc}
\hline Bis-bibenzyls & $\begin{array}{c}\mathrm{KB} \\
(\mu \mathrm{M})\end{array}$ & $\begin{array}{c}\mathrm{KB}+\mathrm{VLB} \\
(\mu \mathrm{M})\end{array}$ & $\begin{array}{c}\text { KB-VLB* } \\
(\mu M)\end{array}$ & $\begin{array}{c}\text { DNA polymerase-b } \\
(\mu \mathrm{M})\end{array}$ & $\begin{array}{c}\text { HIV-1 } \\
(\mu \mathrm{g} / \mathrm{mL})\end{array}$ \\
\hline Marchantin A (72) & 3.7 & 1.3 & 2.7 & 97.5 & 11.5 \\
\hline Marchantin B (75) & 3.2 & 9.3 & 4.0 & 14.4 & 9.3 \\
\hline Marchantin D (76) & 10.8 & $>20.0$ & $>20.0$ & 55.4 & 23.7 \\
\hline Marchantin E (77) & 7.6 & 1.6 & 2.9 & 20.0 & 21.2 \\
\hline Perrottetin F (81) & $>20.0$ & 12.6 & 9.5 & 14.3 & 5.3 \\
\hline Paleatin B (82) & $>20.0$ & $>20.0$ & $>20.0$ & 18.5 & 22.1 \\
\hline Pusilatin B (125) & 13.1 & 15.3 & 11.9 & 13.0 & $* *$ \\
\hline Pusilatin C (126) & 13.8 & 7.1 & 11.7 & 5.16 & $* *$ \\
\hline
\end{tabular}

*VLB: Vinblastine: ${ }^{* *}$ not tested

\subsubsection{Tubulin polymerization inhibition}

Marchantin C (74) strongly inhibited the growth of human cervical tumor xenografts in nude mouse and decreased the quantity of microtubules in a time- and dose-dependent manner at the G2/M phase in human glioma tumor cells and HeLa (human cervical adenocarcinoma cell line) cells at 8-16 $\mu M[43,66]$. The same compound (74) decreased the polymerization rate of gross tubulin, similar to the microtubule depolymerizor, vincristine, at 8-24 $\mu M$. These results indicated that $\mathbf{7 4}$ plays the same role in microtubule depolymerization in both its apoptotic effects in the cell and subsequent antitumor activity in vivo. Compound 74 is a novel microtubule inhibitor that induces mitotic arrest of tumor cells and suppresses tumor cell growth. The structure of marchantin $\mathrm{C}$ is distinct from classical microtubule inhibitors like colchicine, paclitaxel, vinblastine, and vincristine. However, this macrocyclic bis-bibenzyl may be regarded as a potential antitumor agent as a result of inhibiting microtubule polymerization $[43,66]$. 
Isoplagiochins A (128) and B (129) isolated from Plagiochila fruticosa inhibited the polymerization of tubulin with $I C_{50}$ values of 50 and $25 \mu M$. The dihydro derivatives of both 128 and 129 were found to be inactive $\left(I C_{50}>100 \mu M\right)$, and, when compared with the parent compounds, indicated that a restricted biaryl ring system is favorable for tubulin binding. A Monte Carlo search showed that the presence of two aromatic rings connected by a two-carbon bridge with a double bond may serve to maintain the backbone conformation [67].

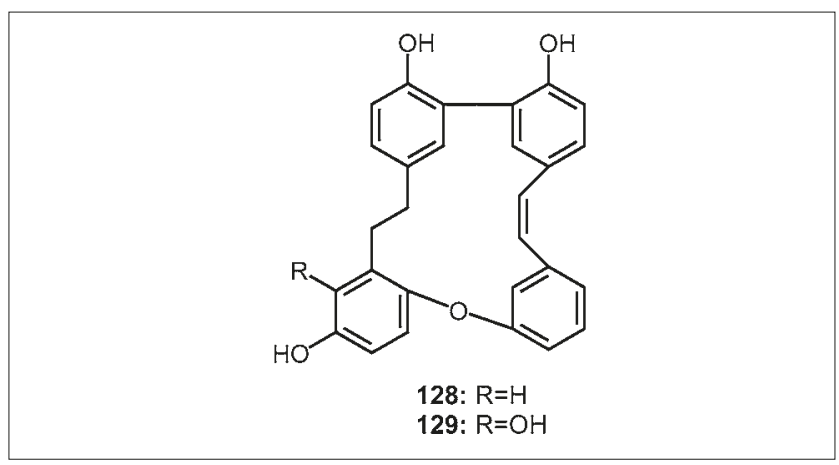

\section{CHEMICAL CONSTITUENTS OF INEDIBLE FUNGI}

\subsection{Introduction}

There are about 1500 identified fungi in Japan among which 300 species are edible, 1150 inedible and 50 toxic. The chemical constituents of toxic and edible fungi have been fully studied. Recently, many biologically interesting compounds were isolated from inedible mushrooms by our group and their structures and biological activity reported $[68,69]$.

\subsection{Bioactive compounds from a few inedible fungi}

The biological properties of the terpenoids and aromatic compounds and acetogenins isolated from inedible fungi in our laboratory are: 1) cytotoxic, 2) anti-HIV-1, 3) anti-HSV, 4) antimicrobial and antifungal, 5) antitumor promotion, 6) insecticidal, 7) nematocidal, 8) antifeedant against snail and slug, 9) plant growth inhibitory, 10) anti-Alzheimer disease, 11) superoxide anion release inhibitory, 12) anticholestemic activity, and 13) spider female sex pheromone production.

\subsubsection{Cytotoxic compounds from Cryptoporus volvatus and Daldinia species}

The fungus Cryptoporus volvatus belonging to the Polyporaceae grows on decayed pine tree and its bruiting body emits resinous smell by which insects such as Parabolitophagus felix and Ischnodactylus loripes are attracted. The wet and dried fruiting bodies contain surprisingly strong bitter principles. The fractionation of the ethyl acetate extracts from $40 \mathrm{~kg}$ of wet fungus gave $20 \mathrm{~g}$ order of cryptoporic acids A (=CPA-A) (130), CPA-B (131), CPA-C (132), CPA-D (133), CPA-F (135), CPA-G (136), together with CPA-E $(\mathbf{1 3 4}, 700 \mathrm{~g})$ as the major component. Compounds 130-136 indicated CPA-F (135), CPA-G (136). Compounds 130-136 indicated very strong inhibition effect for superoxide anion radical from guineapig macrophage induced by $\mathrm{O}_{2}^{-}$radical stimulant formyl methionyl leucyl phenylalanine (FMLP) at a concentration of $13,25,0.07,0.1,0.05,0.3$ and $0.15 \mu \mathrm{g} / \mathrm{mL}$, respectively. CPA-C (133) also possessed the $88 \%$ of inhibitory effect for superoxide anion release from rabbit polymorphonuclear

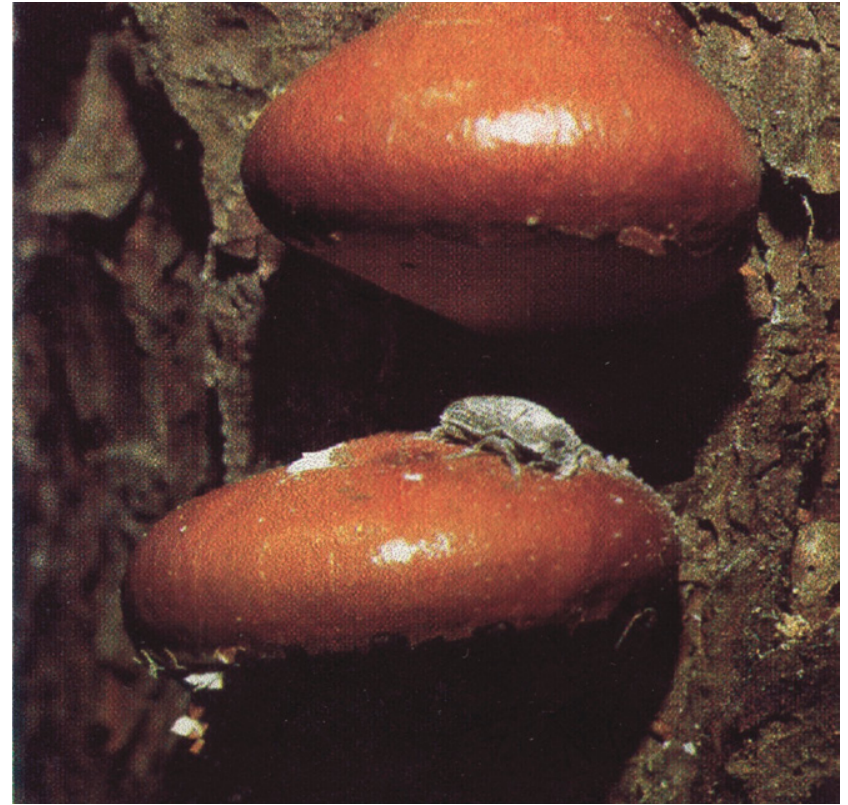

Figure 8. Cryptoporus volvatus (Polyporaceae) on dead pine tree.

leucocyte induced by $\mathrm{O}_{2}^{-}$radical stimulant FMLP at a concentration of $6 \mu \mathrm{g} / \mathrm{mL}^{2}$ [70]. Those bitter drimanes with isocitric acid moiety showed cytotoxicity against $\mathrm{KB}$, Lui, LNCaP ad ZR-75-1 cancer cell lines as shown in Table 3. The cytotoxicity of the permethylated CPA series is more potent than that of their naturally occurring CPAs [Asakawa \& Hahimoto, unpublished results].

The same CPA series (130-136) showed inhibitory effect at a concentration of $>50,>50,40,>50,>50,>50$ and $>50 \mu \mathrm{g} / \mathrm{mL}$ against lysosome enzyme release from rat peritoneal neutrophil cell stimulated by FMLP $\left(10^{-6} \mathrm{M}\right)$ and cytochalasin B $(5 \mu \mathrm{g} / \mathrm{ml})$ [70].

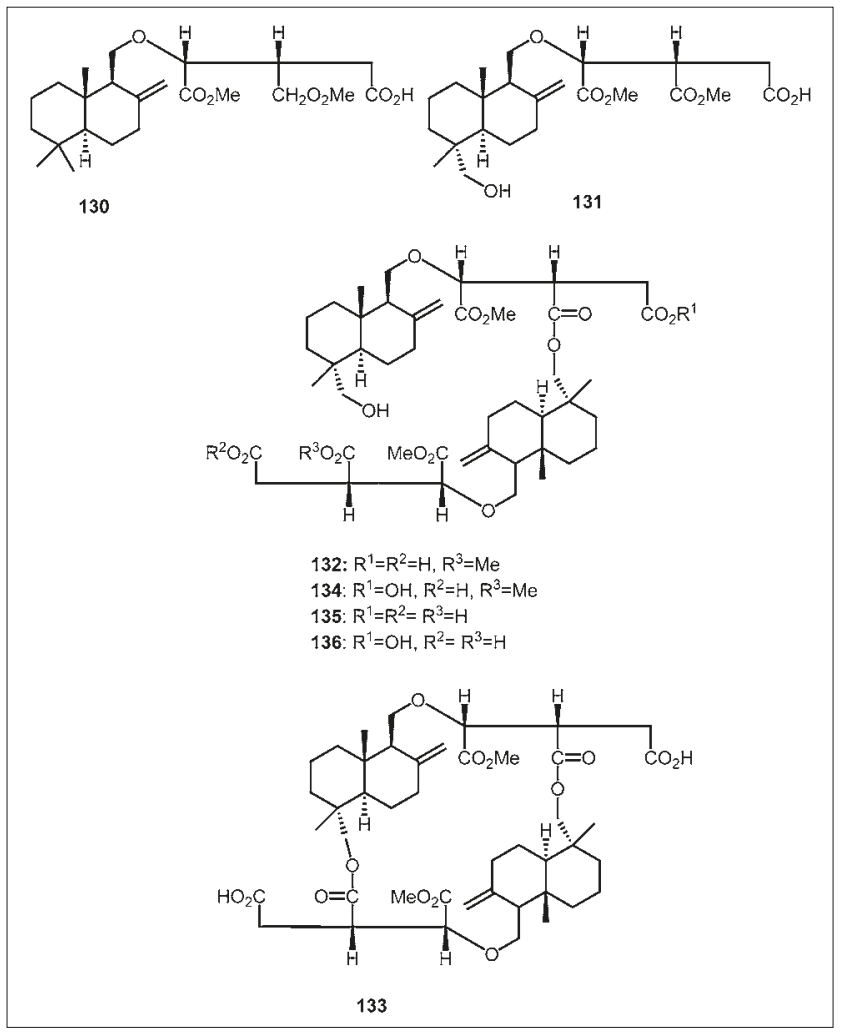


Table 3. Cytotoxicity testing ( $E D_{5}: \mu \mathrm{g} / \mathrm{ml}$ ) of cryptoporic acids $A-G$ and their methylated derivatives on KB, KB-V, Lu1, LNCaP and ZR-75-1 cell lines.

\begin{tabular}{lcccccc}
\hline \multicolumn{1}{c}{ Samples } & KB & KB-V $(+V L B)^{\mathrm{a}}$ & KB-V $(-V L B)^{\mathrm{b}}$ & Lu1 & LNCaP & ZR-75-1 \\
\hline Cryptoporic acid-A (130) & $>20$ & $>20$ & $>20$ & $>20$ & $>20$ & $>20$ \\
CPA-A Me3 & 2.3 & 2.6 & 3.4 & $>20$ & $>20$ & 12.2 \\
CPA-B(131) & $>20$ & $>20$ & $>20$ & $>20$ & $>20$ & $>20$ \\
CPA-B Me3 & $>20$ & 3.8 & $>20$ & $>20$ & $>20$ & $>20$ \\
CPA-C(132) & $>20$ & $>20$ & $>20$ & $>20$ & $>20$ & 12.9 \\
CPA-C Me5 & 14.2 & 3.8 & $>20$ & $>20$ & 15.7 & 13.0 \\
CPA-D (133) & $>20$ & $>20$ & $>20$ & $>20$ & $>20$ & 14.5 \\
CPA-D Me4 & $>20$ & $>20$ & $>20$ & $>20$ & $>20$ & $>20$ \\
CPA-E(134) & $>20$ & $>20$ & $>20$ & $>20$ & $>20$ & $>20$ \\
CPA-E Me5 & $>20$ & $>20$ & $>20$ & $>20$ & $>20$ & $>20$ \\
CPA-F(135) & $>20$ & $>20$ & $>20$ & $>20$ & $>20$ & $>20$ \\
CPA-G(136) & $>20$ & $>20$ & $>20$ & $>20$ & $>20$ & $>20$ \\
\hline
\end{tabular}

a: $+V L B=$ presence of vinblastine; ${ }^{b}:-V L B=$ absence of vinblastine

An unidentified Daldinia species belonging to the Xylariaceae produces cytochalasin series belonging to 10-pheyl-(11) class of cytochalasins and 10-phenyl-22-oxa(12)-cytochalasin [71]. Compounds 137-141 exhibited the cytotoxic activity against KB cell line as shown in Table 4 [Hashimto \& Asakawa, unpublished results].

Table 4. Cytotoxic effect of cytochalasins against KB cells

\begin{tabular}{ccc}
\hline Cytochalasins & \multicolumn{2}{c}{ Inhibition \% } \\
\cline { 2 - 3 } & KB cell at $10^{-5} M$ & KB cell at $10^{-6} M$ \\
\hline 137 & 96 & 58 \\
138 & 84 & 50 \\
139 & 89 & 44 \\
140 & 84 & 50 \\
141 & 96 & 28 \\
\hline
\end{tabular}

\subsubsection{Antiviral compounds from inedible fungi}

The cryptoporic acids isolated from C. volvatus showed not only cytotoxicity against cancer cell lines but also inhibitory activity against HIV 1 RT (p66) as shown in Table 5. Among which, two permethylated products, cryptoporic acid B (131) trimethyl ether and cryptoporic acid E (134) pentamethyl ether showed highest HIV-1 inhibitory activity [Hashimoto \& Asakawa, unpublished results].

Table 5. Inhibitory effect of cryptoporic acids A-G and their derivatives on HIV-1 RT (p66).

\begin{tabular}{lcc}
\hline Samples & $\begin{array}{c}\% \text { Inhibitory at } \\
20 \mu \mathrm{g} / \mathrm{mL}\end{array}$ & $\mathrm{IC}_{50}(\mu \mathrm{g} / \mathrm{mL}), \mathrm{r}^{2}$ \\
\hline Cryptoporic acid A (=CPA-A) (130) & 16.10 & Inactive \\
CPA-A Me3 & 2.23 & Inactive \\
CPA-B (131) & 5.77 & Inactive \\
CPA-B Me3 & 2.23 & $61.0 \mu \mathrm{g} / \mathrm{mL}, \mathrm{r}^{2}=0.992$ \\
CPA-C (132) & 99.6 & Inactive \\
CPA-C Me5 & 0.00 & Inactive \\
CPA-D (133) & 25.40 & Inactive \\
CPA-D Me4 & 0.00 & Inactive \\
CPA-E (134) & 19.00 & Inactive \\
CPA-E Me5 & 3.75 & $42.2 \mu \mathrm{g} / \mathrm{mL}, \mathrm{r}^{2}=0.889$ \\
CPA-F (135) & 99.7 & Inactive \\
CPA-G (136) & 37.3 & Inactive
\end{tabular}

Kashiwada et al. [72] reported that Rododendron dauriaum contained (-)-daurichromenic aicd (145) which showed potent anti-HIV activity as shown in Table 6. The inedible fungous Albatrellus dispansus produces a large amount of grifolic acid (146), along with grifolic acid methyl ether (143) and grifolin
Table 6. Anti-HIV I activity of daurichomenic acid and grifolins

\begin{tabular}{lcc}
\hline Compounds & $\mathrm{ED}_{50} \mu \mathrm{g} / \mathrm{mL}^{\mathrm{a}}$ & $\mathrm{CC}_{50} \mu \mathrm{g} / \mathrm{mL}^{\mathrm{b}}$ \\
\hline Grifolic acid (142) & 40 & 40 \\
Grifolic acid methyl ether(143) & 53 & 53 \\
Grifolin (144) & 38 & 38 \\
(-)-Daurichromenic acid (145) & 0.00056 & 557 \\
\hline
\end{tabular}

$\alpha: 50 \%$ effective concentration; $\beta: 50 \%$ cytotoxic concentration
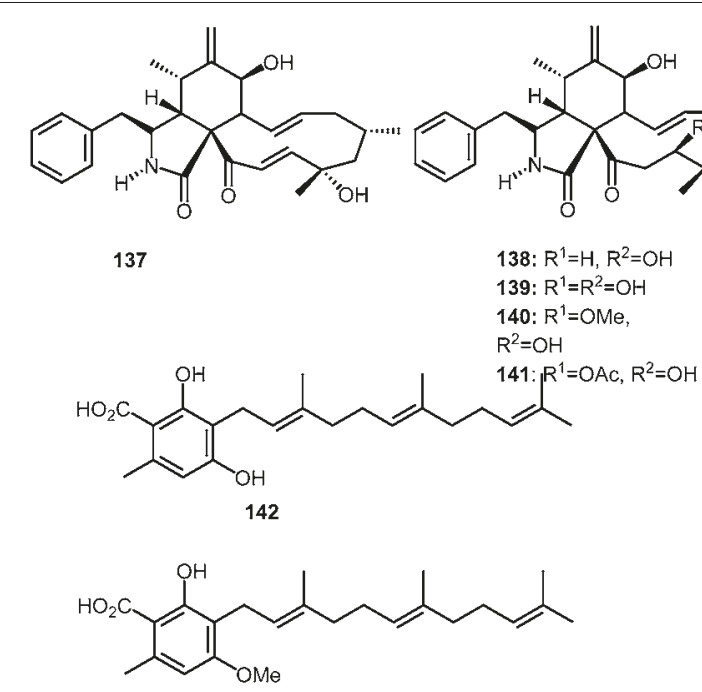

143<smiles>CC(C)=CCC/C(C)=C/CC/C(C)=C/Cc1c(O)cc(C)cc1O</smiles>

144<smiles>CC(C)=CCC/C(C)=C/CC[C@]1(C)C=Cc2c(cc(C)c(C(=O)O)c2O)O1</smiles>

(144). Acidic treatment of $\mathbf{1 4 2}$ gave racemate daurichromenic acids which was purified by HPLC using chiral column to give natural (-)-daurichromenic acid (145) [Hashimoto \& Asakawa, unpublished results]. Lycogala epidendrum, a smile mould belonging to the Myxomycetes elaborates unique pyrroledicarboxylates attached to two indoles,, named lycogarubins A-C (146-148) of which compound 148 showed anti-HSV virus activity at a concentration of $\mathrm{IC}_{50} 17.2 \mu \mathrm{g} / \mathrm{mL}$ in vitro [68].

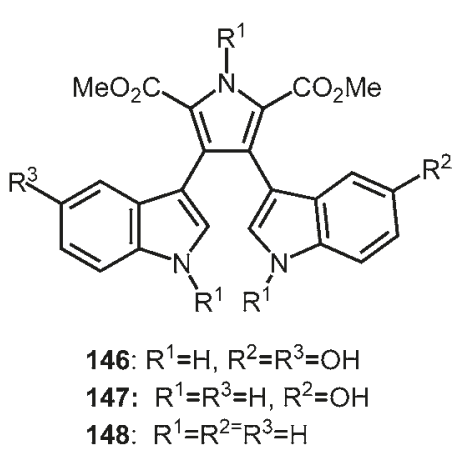




\section{CONCLUSION}

The bryophytes and inedible fungi are found in whole the world. They are generally very tiny organisms. However, they produce a great number of secondary metabolites, including pungent and bitter terpenoids and polyphenolic compounds or nitrogen containing compounds many of which show interesting biological activity such as cytotoxicity, antiviral activity. Only $5 \%$ of the total bryophytes have been chemically investigated since 20 century. Further search on the secondary metabolites of bryophytes and inedible fungi will results in the discovery of many different compounds with biologically and pharmaceutically interest.

\section{Acknowledgements}

The author thank the Emeritus Prof. G. A. Cordell (Illinois Univ. at Chicago), Prof. J. M. Pezzuto (Univ. of Hawaii, Hilo), and Prof. T. Kuzuhara for their biological test of bis-bibenzyls. Thanks are indebted to Prof. R. Gradstein (National Museum of Natural History, Paris), Dr. M, Mizutani (Hattori Botanical Laboratory, Nichinan, Japan) for their collection and identification of liverworts. A part of this work was supported by a Grant-in-Aid for the Scientific Research (A) (No. 11309012), and the Open and Senryaku Research from the Ministry of Education, Culture, Sports, Science and Technology.

\section{REFERENCES}

1. Asakawa Y, Huneck S, Toyota M, Takemoto T, Suire C. Mono- and sesquiterpenes from Porella arboris-vitae. J Hatt Bot Lab. 1979; 46: $163-167$.

2. Asakawa Y. Chemical constituents of the Hepaticae. In: Herz W, Grisebach H, Kirby G.W, eds. Progress in the chemistry of organic natural products. Vienna, Springer, 1982. 42, p.1-285.

3. Asakawa Y. Chemical constituents of the bryophytes. In: Herz W, Kirby WB, Moore RE, Steglich W, Tamm Ch. eds. Progress in the chemistry of organic natural products. Vienna, Springer, 1995.p.1- 618.

4. Asakawa Y, Ludwiczuk A, Nagashima F. Chemical constituents of bryophytes: Bio- and chemical diversity, biological activity and chemosystematics. In: Kinghorn DA, Falk H, Kobayashi J. eds. Progress in the chemistry of organic natural products. Springer, Vienna, 2013.p. $1-796$.

5.Ludwiczuk A, Asakawa Y. Distribution of terpenoids and aromatic compounds in selected southern hemispheric liverworts. Fieldiana Bot. 2008; 47: 37-58.

6. Ludwiczuk A, Asakawa Y. Chemosystematics of the liverworts collected in Borneo. Tropic Bryol. 2010; 31: 33-42.

7.Ludwiczuk A, Nagashima F, Gradstein SR, Asakawa Y. Volatile Components from the selected Mexican, Ecuadorian, Greek, German and Japanese liverworts. Nat Prod Commun. 2008; 3: 133-140.

8. Ludwiczuk A, Komala I, Pham A, Bianchini JP, Raharivelomanana P, Asakawa Y. Volatile components from selected Tahitian liverworts. Nat. Prod. Commun. 2009; 4: 1387-1392.

9. Asakawa Y. Phytochemistry of bryophytes: biologically active terpenoids and aromatic compounds from liverworts. In: Romeo J. ed. Phytochemicals in human health protection, nutrition, and plant defense. New York, Kluwer Academic/Plenum Publishers, 1999.p.319_ 342 .

10. Asakawa Y. Liverworts - potential source of medicinal compounds. Curr Pharm Design. 2008; 14: 3067-3088.

11. Asakawa Y. Recent advances of biologically active substances from Marchantiophyta. Nat Prod Commun. 2008; 3: 77-92.

12. Asakawa Y. Biologically active substances from bryophytes. In: Chopra RN, Bhatla SC. eds. Bryophyte development: Physiology and biochemistry. Boca Raton, CRC Press, 1990.p.259-287.

13. Asakawa Y. Terpenoids and aromatic compounds with pharmacological activity from bryophytes. In: Zinsmeister DH, Mues R, eds. Bryophytes: Their chemistry and chemical taxonomy. Oxford, Oxford University Press, 1990.p.369-410.
14. Mohamed H, Baki BB, Nasrulhaq-Boyce A, Lee PK Y. eds. In: Bryology in the new millenium. Kuala Lumpur, University of Malaya, 2008.p.1-513.

15. Inoue H. Bryophytes as a indicator of continental drift (Gondwana land). Kagakuasahi 1988; 8: 116-121.

16.von Reu $\beta$ SH, König WA. Corsifurans A-C, 2-arylbenzofurans of presumed stilbenoid origin from Corsinia coriandrina (Hepaticae). Phytochemistry 2004; 65: 3113-3118.

17. Toyota M, Tanimura K, Asakawa Y. Cytotoxic 2,3-Secoaromadendranetype sesquiterpenoids from the liverwort Plagiochila ovalifolia. Planta Med. 1998; 64: 462-464

18. Shu YF, Wei HC, Wu CL. Sesquiterpenoids from liverworts Lepidozia vitrea and L. fauriana. Phytochemistry 1994; 37: 773-776.

19.Lu, Z. -Q., Fan, P. -H., Ji, M., Lou, H. -X. Terpenoids and bisbibenzyls from Chinese liverworts Conocephalum conicum and Dumortiera hirsuta. J. Asian Nat. Prod. Res. 2006; 8: 187-192.

20. Komala I. Ito T, Nagashima F, Yagi Y, Asakawa Y, Cytotoxic, radical scavenging and antimicrobial activities of sesquiterpenoids from the Tahitian liverwort Mastigophora diclados (Brid.) Nees (Mastigophoraceae). J Nat Med. 2010; 64: 417-422.

21. Wang Y, Harrison LJ, Tan BC. Terpenoids from the liverwort Chandonanthus hirtellus. Tetrahedron 2009; 65: 4035-4043.

22. Komala I, Ito T, Nagashima F, Yagi Y, Asakawa Y. New sesqui- and diterpenoids from the liverwort Chandonanthus hirtellus. The $53^{\text {rd }}$ Symposium on Chemistry of Terpenes, Essential Oils and Aromatics; November 7-9, 2009; Nara, Japan. Symposium Papers, p.266-268.

23. Wu C, Gunatilaka AAL, McCabe FL, Johnson RK, Spjut RW, Kingston DG.I. Bioactive and other sesquiterpenes from Chiloscyphus rivularis. J Nat Prod. 1997; 60: 1281-1286.

24. Baek SH, Perry NB, Lorimer SD, ent-Costunolide from the liverwort Hepatostolonophora paucistipula. J. Chem. Research (S). 2003; 14-15.

25. Kim, Y. C., da S. Bolzani, V., Baj, N., Gunatilaka, A. A. L., Kingston, D. G. I. A DNA-damaging sesquiterpene and other constituents from Frullania nisquallensis. Planta Med. 1996; 62: 61-63.

26. Burgess EJ, Larsen L, Perry NB. A Cytotoxic sesquiterpene caffeate from the liverwort Bazzania novae-zelandiae. J Nat Prod. 2000; 63: 537-539.

27. Perry NB, Foster LM. Sesquiterpene/quinol from a New Zealand liverwort, Riccardia crassa. J Nat Prod. 1995; 58: 1131-1135.

28. Komala I, Ito T, Nagashima F, Yagi Y, Kawahata M, Yamaguchi K, et al. Zierane sesquiterpene lactone, cembrane and fusicoccane diterpenoids, from the Tahitian liverwort Chandonanthus hirtellus. Phytochemistry 2010; 71: 1387-1394.

29. Scher JM, Burgess EJ, Lorimer SD, Perry NB. A cytotoxic sesquiterpene and unprecedented sesquiterpene-bisbibenzyl compounds from the liverwort Schistochila glaucescens. Tetrahedron 2002; 58: 7875-7882.

30. Lorimer, S. D., Perry, N. B., Burgess, E. J., Foster, L. M. 1-Hydroxyditerpenes from two New Zealand liverworts, Paraschistochila pinnatifolia and Trichocolea mollissima. J Nat Prod. 1997; 60: 421-424.

31. Perry NB, Burgess E J, Tangney RS. Cytotoxic 8,9-secokaurane diterpenes from a New Zealand Liverwort, Lepidolaena taylorii. Tetrahedron Lett. 1996; 37: 9387-9390.

32. Perry NB, Burgess EJ, Baek SH, Weavers RT, Geis W, Mauger AB. 1999. 11-Oxygenated cytotoxic 8,9-secokauranes from a New Zealand liverwort, Lepidolaena taylorii. Phytochemistry 1999; 50: 423-433.

33. Nagashima F., Kondoh M, Uematsu T, Nishiyama A, Saito S, Sato M, et al. Cytotoxic and apoptosis-Inducing ent-kaurane-type diterpenoids from the Japanese liverwort Jungermannia trunctata Nees. Chem Pharm Bull. 2002; 50: 808-813.

34. Perry NB, Burgess EJ, Foster LM, Gerard PJ, Toyota M, Asakawa Y., 2008. Insect antifeedant sesquiterpene acetals from the liverwort Lepidolaena clavigera. 2. Structures, artifacts and activity. J Nat Prod. 1998; 71: 258-261.

35. Perry NB, Burgess EJ, Baek SH, Weavers RT. The First atisane diterpenoids from a liverwort: Polyols from Lepidolaena clavigera. Org Lett. 2001; 3: 4243-4245.

36. Neves M, Morais R, Gafner S, Hostettmann K. Three triterpenoids and one flavonoid from the liverwort Asterella blumeana grown in vitro. Phytotherapy Res. 1998; 12: 21-24.

37. Wong SM, Oshima Y, Pezzuto J, Fong H, Farnsworth N. Plant anticancer agents XXXIX. Triterpenes from Isis missouriensis (Iridaceae). J Pharm Sci. 1986; 75: 317-320.

38. Komala I, Ito T, Nagashima F, Yagi Y, Asakawa Y. Cytotoxic bibenzyls, germacrane- and pinguisane-type sesquiterpenoids from the Indonesian, Tahitian and Japanese liverworts. Nat Prod Commun. 2011; 6: 303-309.

39. Asakawa Y, Toyota M, Tori M, Hashimoto T. Chemical structures of macrocyclic bis(bibenzyls) isolated from liverworts (Hepaticae). Spectroscopy 2000; 14: 149-175. 
40. Asakawa Y, Matsuda R. Riccardin C, a novel cyclic bibenzyl derivative from Reboulia hemisphaerica. Phytochemistry 1982; 21: 2143-2144.

41. Huang WJ, Wu CL, Lin CW, Chi LL, Chen PY, Chiu CJ, et al. Marchantin A, a cyclic bis(bibenzyl ether), isolated from the liverwort Marchantia emarginata subsp. tosana induces apoptosis in human MCF-7 breast cancer cells. Cancer Lett. 2010; 291: 108-119.

42.Xie CF, Qu JB, Wu XZ, Liu N, Ji M, Lou HX. Antifungal macrocyclic bis(bibenzyls) from the Chinese liverwort Plagiochasma intermedium L. Nat Prod. Res. 2010; 24; 515-520.

43. Shi YQ, Liao YX, Qu XJ, Yuan HQ, Li S, Qu JB, et al. Marchantin C, a macrocyclic bisbibenzyl, induces apoptosis of human glioma A172 cells. Cancer Lett. 2008; 262: 173-182.

44. Shi YQ, Qu XJ, Liao YX, Xie CF, Cheng YN, Li S. et al. Reversal effect of a macrocyclic bisbibenzyl plagiochin $\mathrm{E}$ on multidrug resistance in adriamycin-resistant K562/A02 cells. Eur. J. Pharmacol. 2008; 584: $66-71$.

45. Speicher A, Groh M, Zapp J, Schaumloffel A, Knauer M, Bringmann G.. Synthesis-driven structure revision of 'plagiochin E', a highly bioactive bisbibenzyl. Synlett. 2009; 1852-1858.

46. Lorimer SD, Perry NB. Antifungal hydroxyacetophenones from the New Zealand liverwort, Plagiochila fasciculata. Planta Med. 1994; 60: 386-387.

47. Perry NB, Foster LM, Lorimer SD, May BCH, Weavers RT, Toyota M, et al. Isoprenyl phenyl ethers from liverworts of the genus Trichocolea: Cytotoxic activity, structural corrections, and synthesis. J Nat Prod. 1996; 59: 729-733.

48. Baek SH, Oh HJ, Lim JA, Chun HJ, Lee HO, Ahn JW, et al. Biological activities of Methyl-4-[[(2E)-3,7-dimethyl-2,6-octadienyl]oxy]-3hydroxybenzoate. Bull. Korean Chem Soc. 2004; 25: 195-197.

49. Nagashima F, Kasai W, Kondoh M, Fujii M. Watanabe Y, Braggins J. E, et al. New ent-kaurene-type diterpenoids possessing cy totoxicity from the New Zealand liverwort Jungermannia species. Chem Pharm Bull. 2003; 51: 1189-1192.

50. Nagashima F, Kondoh M, Fujii M, Takaoka S, Watanabe Y, Asakawa Y. Novel cytotoxic diterpenoids from the New Zealand liverwort Jungermannia species. Tetrahedron 2005; 51: 4531-4544.

51. Nagashima F, Kondoh M, Kawase M, Simizu S, Osada H, Fuji M, et al. Apoptosis-inducing properties of ent-kaurene-type diterpenoids from the liverwort Jungermannia trunctata. Planta Med. 2003; 69: 377-379.

52. Kondoh M, Suzuki I, Sato M, Nagashima F, Simizu S, Harada M.et al. 2004. Kaurene diterpene induces apoptosis in human leukemia cells partly through a caspase-8-dependent pathway. J Pharmacol Exp Ther. 2004; 311: 115-122.

53. Suzuki I, Kondoh M, Harada M, Koizumi N, Fujii M, Nagashima F, et al. An ent-kaurene diterpene enhances apoptosis induced by tumor necrosis factor in human leukemia cells. Planta Med. 2004; 70: 723-727.

54. Suzuki I, Kondoh M, Nagashima F, Fujii M, Asakawa Y, Watanabe Y A comparison of apoptosis and necrosis induced by ent-kaurene-type diterpenoids in HL-60 cells. Planta Med. 2004; 70: 401-406.

55. Kondoh M, Nagashima F, Suzuki I, Harada M, Fuji M, Asakawa Y, et al. Induction of apoptosis by new ent-kaurene-type diterpenoids isolated from the New Zealand liverwort Jungermannia species. Planta Med. 2005; 71: 1005-1009.
56. Kondoh M, Suzuki I, Harada M, Nagashima F, Fuji M, Asakawa Y. et al. Activation of p38 mitogen-activated protein kinase during ent$11 \alpha$-hydroxy-16-kauren-15-one-induced apoptosis in human leukemia HL-60 cells. Planta Med. 2005; 71: 275-277.

57. Izumi S, Nishio Y, Takashima O, Hirata T. Monoterpenoids, potent inducers of apoptosis in the cells of Marchantia polymorpha. Chem Lett. 1997; 837-838.

58. Guo DX, Du Y, Wang YY, Sun LM, Qu JB, Wang XN, et al. Secondary metabolites from the liverwort Ptilidium pulcherrimum. Nat Prod Commun. 2009; 4: 1319-1322.

59. Nozaki H, Hayashi KI, Nishimura N, Kawaide H, Matsuo A, Takaoka D. 2007. Momilactone A and B as allelochemicals from moss Hypnum plumaeforme: First occurrence in bryophytes. Biosci Biotechnol Biochem 2007; 71: 3127-3130.

60. Kim SJ, Park HR, Park E, Lee SC. Cytotoxic and antitumor activity of momilactone B from rice hulls. J Agric Food Chem. 2007; 55: 1702-1706.

61. Zheng G.Q, Ho DK, Elder PI, Stephens RE, Cottrell CE, Cassady JM. Ohioensins and pallidisetins: Novel cytotoxic agents from the moss Polytrichum pallidisetum. J Nat Prod. 1994; 57: 32-41.

62. Fu P, Lin S, Shan L, Shen, YH, Tang J, Liu RH, et al. Constituents of the moss Polytrichum commune. J Nat Prod. 2009; 72: 1335-1337.

63. Asakawa Y, Ludwiczuk, A. Distribution of cyclic bis-bibenzyls in the Marchantiophyta (liverworts), ferns and higher plants and their biological activities, biosynthesis, and total synthesis. Heterocycles. 2012; 86: 891-917.

64. Iwai Y, Murakami K, Gomi Y, Hashimoto T, Asakawa Y, Okuno Y, et al. Anti-influenza activity of marchantins, macrocyclic bisbibenzyls contained in liverworts. PLoS ONE. 2011; 6: 19825.

65. Yoshida T, Hashimoto T, Takaoka S, Kan Y, Tori M, Asakawa Y. Phenolic constituents of the liverwort: Four novel cyclic Bisbibenzyl dimers from Blasia pusilla L. Tetrahedron 1996; 52: 14487-14500.

66. Shi YQ, Zhu CJ, Yuan HQ, Li BQ, Gao J, Qu XJ, et al. Marchantin C, a novel microtubule inhibitor from liverwort with anti-tumor activity both in vivo and in vitro. Cancer Lett. 2009; 276: 160-170.

67. Morita H, Tomizawa Y, Tsuchiya T, Hirasawa Y, Hashimoto T, Asakawa Y. Antimitotic activity of two macrocyclic bis(bibenzyls), isoplagiochins $\mathrm{A}$ and B from the liverwort Plagiochila fruticosa. Bioorg Med Chem Lett. 2009; 19: 493-496.

68. Hashimoto T, Yasuda A, Akazawa K, Takaoka S, Tori M, Asakawa Y. Three novel dimethyl pyrroledicarboxylate, lycogarubin A-C, from the Myxomycetes Lycogala epidendrum. Tetrahedron Lett. 1994; 35: 2559-2560.

69. Quang DN, Hashimoto T, Asakawa Y. Inedible mushrooms, a good source of biologically active compounds. J Chem Rec. 2006; 6: 79-99.

70. Asakawa Y, Hashimoto T, Mizuno Y, Tori M. Cryptoporic acids A-G, drimane-type sesquiterpenoid ethers of isocitoric acid from the fungus Cryptoporus volvatus. Phytochemistry 1992; 31: 579-592.

71. Buchanan MS, Hashimoto T, Asakawa Y. Cytochalasins from a Daldinia sp. of fungus. Phytochemistry 1996; 41: 821-828.

72. Kashiwada Y, Yamazaki K, Ikeshiro Y, Yamagishi T, Fujioka T, Mihashi $\mathrm{K}$, et al. 2001. Isolation of rhododaurichromanic acid B and the antiHIV principles rhododaurichromanic acid A and rhododaurichromenic acid from Rhododendron dauricum. Tetrahedron. 2001; 57:1559-15. 